\title{
Investigation of Basin Characteristics: Implications for Sub-basins Level Flood Peak and Vulnerability Assessment
}

Rajeev Ranjan ( $\nabla$ engrajeevcivil12@gmail.com )

Indian Institute of Remote Sensing Dehradun Uattarkhand IN https://orcid.org/0000-0003-4939-1340

\section{Pankaj R. Dhote}

Indian Institute of Remote Sensing

Praveen K. Thakur

Indian Institute of Remote Sensing

Shiv P. Aggarwal

Indian Institute of Remote Sensing

\section{Research Article}

Keywords: Flood vulnerability, Hydrological modelling, Indicator-based method, GIS, Flood peak

Posted Date: June 24th, 2021

DOI: https://doi.org/10.21203/rs.3.rs-588510/v1

License: (a) (i) This work is licensed under a Creative Commons Attribution 4.0 International License.

Read Full License 


\title{
1 Investigation of Basin Characteristics: Implications for Sub-
}

\section{basins Level Flood Peak and Vulnerability Assessment}

\author{
Rajeev Ranjan ${ }^{1}$, Pankaj R. Dhote ${ }^{1}$, Praveen K. Thakur ${ }^{1}$, Shiv P. Aggarwal ${ }^{1}$
}

${ }^{1}$ Indian Institute of Remote Sensing, ISRO, Dehradun, Uttarakhand, India, 248001

7 Corresponding author: Pankaj R. Dhote (pdh@iirs.gov.in)

\section{Abstract}

10 Flood vulnerability is a significant component in assessing the probable degree of damage to

11 various exposures in hazard conditions. In this study, a semi-distributed event-based hydrological

12 model and indicator-based method were applied to evaluate the sub-basin level flood vulnerability

13 using the Geographical Information System (GIS). The flood peak discharge of each sub-basin

14 corresponding to the 2014 extreme flood of the Jhelum river was related with different sub-basins

15 characteristics (terrain, hydrological, land use and soil) using a theoretical framework under an

16 indicator-based method. The calibrated (2014) and validated (1992, 1997) hydrological model

17 showed Nash-Sutcliffe Efficiency (NSE) of 0.98 and $(0.99,0.99)$ at relatively upstream gauging

18 station Sangam against optimized Curve Number $(\mathrm{CN})$ scaling factor of 0.98. The Anantnag and

19 Kulgam districts, exhibiting multiple sub-basins contributing to the Sangam gauging station, are

20 falling into a highly vulnerable category located in the Jhelum basin's southern part, Greater

21 Himalayan Range. It was also revealed that sub-basins at the upstream of the Jhelum basin are more 
22 vulnerable compared to downstream area, where sub-basin W810 (Greater Himalayan), Anantnag

23 district draining at Sangam gauging site is found as most vulnerable among the all other sub-basins.

24 However, hydrological characteristics control the most vulnerable sub-basin peak discharge rather

25 than other characteristics such as terrain, soil, or Land Use. Outcomes of the study will be helpful

26 in prioritizing the flood mitigation planning not only with respect to the hydrological boundary

27 (sub-basin level) but also with administrative district boundaries. The proposed method is generic

28 and can be applied to any flood-prone river basin.

29 Keywords: Flood vulnerability, Hydrological modelling, Indicator-based method, GIS, Flood peak

\section{1. Introduction}

32 Flooding is recurrent phenomena amongst all-natural catastrophe (earthquake, landslides, forest

33 fires etc.) (Dhar and Nandargi 2003; Jonkman 2005; Aggarwal et al. 2009; Ahmad et al. 2018) that

34 solemnly affects society leading to loss of lives and properties. Natural catastrophes like debris

35 flows and floods are the serious threat for the livelihood of the hilly and mountainous region

36 (Watson and Haeberli 2004; Meraj et al. 2015). In the recent past years, Himalayan regions have

37 encountered major appalling calamitous floods such as floods in Tirthan River, Himachal Pradesh

38 flood (2005); Kosi River, Bihar flood (2008); a flash flood in Leh (2010); floods in Ganga River

39 (2010); Brahmaputra River, Assam flood (2012; a flash flood in Kedarnath, Uttarakhand (2013);

40 and flood in Jhelum River, Jammu and Kashmir (2014) (Bhatt et al. 2017; Dhote et al. 2019; Thakur

41 et al. 2019). Flood is a menace to sustainable development in the Himalayan regions (Ives 2004;

42 Bhatt et al. 2017). There is a need for sub-basin level flood peak characterization using hydrological

43 and geospatial model inputs to facilitate prompt environmental planning in flood-prone areas. This 
44 will establish the direct link between physical phenomenon (flood) and the land attributes

45 (Halwatura and Najim 2013) and atmospheric parameters to minimize the flood damage.

46 The unavailability or limited availability of observational data are the big hindrance in the path of

47 solving real world physical problems using model-based approach (Chaponnière et al. 2008;

48 Keshari et al. 2010; Romshoo et al. 2012; Meraj et al. 2015). The empirical methods, unit

49 hydrograph, rational formulas, watershed models and flood frequency technique are the

50 conventional techniques to estimate the peak design floods (Halwatura and Najim 2013; Aggarwal

51 et al. 2019). The basin characteristics and the required hydrological responses in the basin are the

52 measures for model selection (Hunukumbura et al. 2008; Chouksey et al. 2017). The commonly

53 used Hydrological models for the estimation of precipitation based hydrological responses are,

54 Hydrologic Engineering Centre - Hydrological Modelling System (HEC-HMS), SWAT (Soil

55 Water and Assessment Tool), VIC (Variable Infiltration Capacity), Geomorphological

56 Instantaneous Unit Hydrograph (GIUH), University of British Colombia Watershed Model

57 (UBCWM) etc. (Morid et al. 2002; Milewski et al. 2009; Beyene et al. 2010; Loukas and Vasiliades

58 2014; Nikam et al. 2018; Thakur et al. 2020). U.S. army corps has developed the physical

59 hydrological model i.e. HEC-HMS ( Engineers 2008; Feldman 2000; Scharffenberg \& Fleming

60 2006). It is commonly used to simulate or analyze the event-based hydrological responses such as

61 flood discharge estimation, flood frequency, reservoir spillway capacity, flood forecasting, urban

62 flooding, stream restoration etc. ( Feldman 2000; Tang et al. 2018; Chang et al. 2017; Thakur et al.

63 2020). Huang et al. (2016) has used the event-based hydrological model to identify the dominant

64 hydrological process and suiatble model strategy for the semi-arid catchments. However, fast,

65 accurate and low-cost simulation capability of Artificial Intelligence (AI)-based data-driven

66 models, emerged as an alternative for the conventional method of stream flow simulations (Nourani 
67 et al. 2011; Mehdizadeh et al. 2019). Shamseldin et al. (2007) has attempted to combine the

68 modelled runoff from the different rainfall-runoff models using the comparative study of three other

69 AI-based models such as Artificial Neural Ntework (ANN), Multi-layer Perceptron (MLP), and

70 Radial Basis Functional Neural Network (RBFNN), respectively. Talei and Chua (2012) has studied

71 the influence of lag-time using the event-based rainfall-runoff modelling based on data-driven

72 techniques. He et al. (2014) have simulated the river flow using AI-based hybrid models such as

73 ANN, Adaptive Neuro fuzzy Inference System (ANFIS), and Support Vector Machine (SVM),

74 respectively. Young and Liu (2015) have implemented the hybrid of HEC-HMS (physical-based)

75 and ANN (AI-based) models to develop the rainfall-runoff model to simulate the runoff during

76 Typhoon events.

77 But, the wide applications of HEC-HMS modelling were also reported in the previous studies

78 (Álvarez et al. 2008; Aggarwal et al. 2019). Halwatura \& Najim(2013) focuses on simulation of

79 runoff in a tropical catchment using HEC-HMS model. Abushandi and Merkel(2013) study

80 implemented the HEC-HMS and IHACRES (Identification of unit Hydrographs and Component

81 flows from Rainfall, Evaporation and Stream flow data) modelling to establish the rainfall runoff

82 relations in an arid region of Jordan, estimation of snow-melt using temperature index method in

83 HEC-HMS model (Bobál et al. 2015). Gebre(2015) has simulated the rainfall runoff for upper

84 Blue Nile River basin using HEC-HMS model. Some of the studies where HMS model was applied

85 are; a study by Ibrahim-Bathis and Ahmed (2016) states an integrated application of HEC-HMS

86 model and SCS-CN in ungauged Doddahalla agriculture watershed; rainfall-runoff modelling

87 accounting soil moisture in HEC-HMS model (Razmkhah et al. 2016a), and event based rainfall-

88 runoff modelling (Razmkhah 2016b; Chang et al. 2017). A review on advancements in techniques

89 of flood forecasting is done by the integration of rainfall-runoff modelling and remote sensing based 
90 soil moisture data (Li et al. 2016). Koneti et al. (2018) utilized HEC-HMS model to study the impact

91 of change of Land Use Land and Land Cover change on the dynamics of runoff in Godavari River

92 basin.

93 Perhaps, the combination of two or more technologies is writing the script of a new era of

94 innovations and advancements in the research areas. Integration of Geographic Information System

95 (GIS) with such types of hydrological models not only enhancing the research outcomes but also

96 shows the advancement of technologies in the field of hydrology. Various studies in the past have

97 revealed the strong and valuable existence of GIS in the domain of disaster risk assessment that

98 includes the hazard, vulnerability or susceptibility and risk assessment of catastrophes like floods

99 and landslides using their indicators termed as "indicator-based approach" (Nasiri et al. 2016;

100 Biswas et al. 2021). Multi criteria-based Decision Making (MCDM) Model such as Analytical

101 Hierarchical Process (AHP) is one of the most famous techniques in the field of hazard assessment

102 and in the identification of susceptible or vulnerable areas with the combination of GIS (Chen et al.

103 2015). Stefanidis and Stathis (2013) have used the indicator-based approach to assess the flood

104 hazard zones in northern Greece using MCDM based AHP and GIS. . Integrated flood hazard

105 assessment based on spatial ordered weighted averaging method considering spatial heterogeneity

106 of risk preference was completed using the Indicator-based GIS approach by (Xiao et al. 2017).

107 Chen et al.(2015) made indicator-based flood hazard assessment in the Kujukuri Plain of Chiba

108 Prefecture, Japan, based on GIS and multi-criteria decision analysis. Singh et al. (2020) used GIS-

109 based multi-criteria technique to identify the flash-flood prone reaches in Beas river basin. Vignesh

110 et al. (2020) have implemented MCDM based AHP and GIS combined approach for the

111 identification of suspectibile flood zones in the flood-prone regions of Kanyakumari district using

112 the flood indicators (or influencing factors or triggering factors). Various literatures are also 
113 available on the application of AI-based models in the field of flood hazard predictions or or

114 susceptibility mapping such as Hong et al. (2018), in their study, used MCDM based Stepwise

115 Assessment Ratio Analysis (SWARA) and a hybrid of ANFIS (AI-based) model with Genetic

116 Algorithm (GA) and Differential Evolution (DE) algorithm for the flood susceptibility mapping of

117 Hengfeng County in Jiangxi Province, China; Falah et al. (2019) used the GIS and combined ANN

118 as an AI-based model for the flood susceptibility mapping in data-scarce urban regions of Emam-

119 Ali town, in Mashhad located in Khorasan Razavi Province, Iran; and Termeh et al. (2018) has done

120 flood susceptibility using the ensemble of AI-based ANFIS and metaheuristic models in the Jahrom

121 Township Fars Province.

122 There are several approaches other than MCDM that have been revealed in the available literatures

123 for establishing the functional relationships among the vulnerability and their elements or indicators

124 as 1 . Deductive (z-score transformation, min-max transformation, maximum value or ratio value

125 transformation, etc.) and 2. Inductive approaches (spectral normalization, weight normalization,

126 etc.) to standardize or normalize or rescale them between 0 to 1 (Clark et al. 1998; Wu et al. 2002;

127 Cutter et al. 2003; Yoon 2012; Miyato et al. 2018). However, Kumar et al.(2016); Žurovec et 128 al.(2017) and Choudhary and Badal(2018) have used one of the famous deductive approach 129 developed by Human Development Index (HDI), United Nation Development Program (UNDP's)

130 (Xs et al. 2006) using the functional relationships between the vulnerability and their indicators.

131 Deep learning neural networks have evolved as one of the very effective techniques in this field

132 during the recent years (Huang et al. 2017; Miyato et al. 2018; Sun et al. 2020).

133 Kashmir valley, a part of Himalayan regions is vulnerable to various kinds of natural calamities

134 especially flood due to its mountainous terrain, heavy rainfall including cloud-burst and excessive

135 snow/glacier melting (Bilham et al. 2010; Ebi et al. 2007; Ganju \& Dimri 2004; Maqsood et al. 
137 prone to the flood is approx. 45.640 million hectares, out of which about 0.514 million hectares 138 area lie in the Jammu and Kashmir i.e. $2.3 \%$ of its total geographical area (Planning Commission

139 2011). Climate change has increased the frequency of intense rainfall and flood events around the 140 globe including the North-West Himalayas (Mishra \& Srinivasan 2013; Murari et al. 2001; IPCC

141 2007; Dhote et al. 2018; Nikam et al. 2018; Romshoo et al. 2018; Thakur et al. 2019). The history

142 revealed that in the past, Kashmir valley has encountered many causalities that caused loss of 143 livelihood and properties (Singh and Kumar 2013; Meraj et al. 2015) due to the major flood events 144 (as 879 AD, 1841, 1893, 1903, 1929, 1948, 1950, 1957, 1959, 1992, 1996, 2002, 2006, 2010, 2014 145 etc.,) ( Romshoo et al. 2018), landslides, earthquakes and avalanches (Lawrence 1895; Singh and 146 Kumar 2013). The Kashmir 2014 flood (3262.60 cumec) was similar to 1903 and 1959 floods 147 according to the people of Kashmir (Lawrence 1895; Bhatt et al. 2017; Romshoo et al. 2018) . The 148 heavy and intense rainfall from $1^{\text {st }}$ Sep 2014 to $6^{\text {th }}$ September 2014 led to the worst flood in the 149 Kashmir valley (Kumar and Acharya 2016; Romshoo et al. 2018). The current study emphasizes 150 on the combined utilization of hydrological modelling and indicator-based methods to assess the 151 sub-basins level flood vulnerability in the Jhelum River basin.

\section{2. Study area and data}

\section{$154 \quad 2.1$ Description of the study area: Jhelum River basin}

155 Fig. 1 depicts the geographical location of Jhelum river basin $\left(9,472.14 \mathrm{Km}^{2}\right)$ with an outlet at the 156 Asham, Bandipora district of Jammu and Kashmir. Jhelum River originates from the spring called 157 'Chasma Verinag' lies in the Anantnag district. It is commonly known as Hydaspes in Greek, 158 Vitasta in Sanskrit and Vyath in Kashmir. Jhelum River, a major tributary of Indus River acts as a 
159 ridge rope for the livelihood of Kashmir valley. The Jhelum River basin system comprises of 160 various tributaries, some of them flow from the Pir Panjal range and join the river on left bank while 161 remaining meet the river on right bank, draining from the Himalayan range. High elevation 162 difference can be observed in the basin varying from 1550 to $5347 \mathrm{~m}$. The bowl shape of Kashmir 163 valley is filled with alluvium having steep slopes that may lead to disastrous flood, post heavy 164 rainfall storm of 1-2 hours (Dhar et al. 1982; Ganjoo 2014; Kumar and Acharya 2016).The 165 reclamation of floodplains and low lying areas for the urbanization and agriculture due to the 166 increased population density have increased the flood risk in the Jhelum basin (Census of India 167 2011; Romshoo et al. 2012). The prominent Land Use and Land covers (LULC) and soil types are 168 the measure of surface flow present in the valley, governing the sub-basins flow in the basin. The 169 region has varied LULC types such as Built-up (BU-2.19\%), Crop Land (CL-37.51\%), Evergreen 170 Broadleaves Forest (EBF-34.40\%), Waterbody (WB-1.94\%), Glacier/Snow-Ice (GL/SI-20.62\%), 171 and Shrubland/Wasteland (SL/WL-3.34\%), see Fig.3 and Fig.4. The percentage of Hydrological 172 Soil Group (HSG) in the study area as A-48.78\%, B-25.32\%, C-24.42\%, and D-1.48\%, depict the 173 primarily soil types in the region, see Fig.4.

174 The average annual precipitation in the valley is about $650 \mathrm{~mm}$, as far as the outer hilly region 175 concerned, it receives more than the central valley (Ahmad et al. 2018). The mean temperature in 176 the valley varies from $7.5^{\circ}$ Celsius in the winter to $19.8^{\circ}$ Celsius in the summer season (Bhat et al. 177 2019). The Kashmir valley receives the heavy snowfall in mountainous regions and rainfall in the 178 adjoining plain areas due to two types of meteorological systems named as the barotropic southwest 179 monsoon and baroclinic extra tropical western disturbances ( Sikka 1999; Dhar and Nandargi 2005;

180 ). These disturbances repeat approximately 4 to 5 times per month during monsoon and nearly 6 to 1817 times per month in winter (Nandargi and Dhar 2011; Kumar and Acharya, 2016). The more 
182 activeness of western disturbances in the winter and spring seasons as compare to summer results

183 into the most amount of precipitation during winter and spring (Bhutiyani et al. 2010; Dar et al.

184 2015).

185

186 Fig. 1. Jhelum River basin with outlet, drainages, sub-basins \& gauging sites

\subsection{Data and tools used}

189 The Advanced Land Observing Satellite (ALOS) Phased Array type L-band Synthetic Aperture 190 Radar (PALSAR) Radiometrically Terrain Corrected (RTC) Digital Elevation Model (DEM) 191 acquired from the Alaska Satellite Facility was used in the present study for the DEM hydro192 preprocessing. The Indian Space Research Organisation-Geosphere Biosphere Program (ISRO193 IGBP) 2005, LULC and the National Bureau of Soil Survey and Land Use Planning (NBSSLUP), 194 soil data were used to prepare the Curve Number (CN) Map. The gridded daily rainfall of Indian 195 Meteorological Department (IMD) of the monsoon seasons (1992, 1997, and 2014) were used as

196 the meteorological input in the hydrological model to simulate the flood hydrographs. Tropical 197 Rainfall Measuring Mission (TRMM) 3-hourly rainfall (Sep 2014) was also used in this study to 198 find the basin lag or lag time $\left(\mathrm{T}_{\mathrm{lag}}\right)$ in the river flow induced after the heavy rainfall event of Sep 199 2014. The observed discharge of three gauging stations i.e. Sangam, RamMunshi Bagh and Asham 200 was procured from the Irrigation and Flood control Department, Jammu and Kashmir for calibration 201 and validation of the model. The detail overview of database used in the present study is shown in

202 the Table 1. Tools and software used in the study for the processing of input data are as: (1) HEC203 Geospatial Hydrologic Modeling System (GeoHMS): an extension of ArcGIS 10.3 used for the 204 DEM hydro processing and the generation of basin characteristics to create the setup files for the 
HEC-HMS 4.3, (2) HEC-HMS 4.3: used for the simulation, calibration, sensitivity, and the

206 validation analysis of the model, Arc-GIS 10.3 and Erdas Imagine 2014: used for creating the

207 geospatial environment for the processing the GIS vector and raster image data, respectively.

209 Table 1: Datasets used in the study

211 3. Methodology

212 The methodology adopted to assess sub-basin level flood vulnerability is divided into two primarily

213 sections: (1) setup of hydrological model to extract sub-basin characteristics and flood peak

214 estimation; (2) identification of vulnerable sub-basins by relating flood peak discharge with sub-

215 basin characteristics using indicator-based GIS method. The outline of implemented methodology

216 is shown in Fig.2. The above two sections have been briefly explained in following subsections.

218 Fig. 2. Methodology flowchart

$220 \quad 3.1$ Hydrological modeling using HEC-HMS

\section{3.1.1 Basin characteristics estimation using HEC-GeoHMS}

222 The HEC-Geo HMS interface, an extension of ArcGIS 10.1 was used to establish semi-distributed

223 framework (Feldman 2000; ESRI 2011) for the Jhelum River basin. The user-friendly interface

224 allows the easy generation of basin characteristics for the hydrological model using topographic

225 data. The ALOS PALSAR RTC product was pre-processed that includes the processes such as fill

226 sink, flow direction, flow accumulation, stream definition, stream link, catchment grid delineation,

227 catchment polygon processing, drainage line processing and adjoint catchment processing. The 
228 eight direction (D8) flow model algorithm was used for the preparation of flow direction (Jenson

229 and Domingue 1988). The threshold value used for defining the streams was $100 \mathrm{~km}^{2}$, the stream

230 network was able to mimic the actual drainage pattern as seen in the satellite imagery. The gauging

231 station Asham was defined as an outlet to delineate the Jhelum River basin. For each sub-basin

232 different catchment characteristics were estimated such as river slope, river length, basin slope,

233 longest flow path, basin centroid and centroid longest flow path.

\subsubsection{Hydrological model (HEC-HMS) configuration}

236 The extensively used hydrological model HEC-HMS, developed by the U. S. Army Corps of

237 Engineers Hydrologic Engineering Center was used to simulate flood hydrographs in Jhelum River 238 basin ( Engineers 2008). In order to run the simulation, the model is needed to be configured with

239 well-defined processes such as (1) estimation of initial abstraction/loss (loss model), (2)

240 transformation of excess rainfall into Unit Hydrograph (UH) (transform model), (3) conversion of

241 Direct Runoff Hydrograph (DRH) into flood hydrograph (base flow model), and (4) generation of

242 flood hydrographs at various river sections (routing model); the execution of these processes depend

243 on the algorithms given in the model (Feldman 2000; Scharffenberg and Fleming 2006;).

244 The Soil Conservation Service (SCS)-Curve Number (CN) method was opted for the loss model to 245 estimate the accumulated rainfall excess (Mishra et al. 2004; Soulis and Valiantzas 2012; Prakash 246 and Abhisek 2016; Koneti et al. 2018). The SCS-CN method for the computation of accumulated 247 precipitation excess in the form of stream flow volume depends (Ibrahim-Bathis and Ahmed 2016)

248 on the soil cover i.e. HSG, cumulative rainfall, antecedent moisture and land use. SCS has 249 developed the empirical relationship between initial abstraction $\left(\mathrm{I}_{\mathrm{a}}\right)$ and potential maximum 250 retention (S) (equation 1) (NRCS 1986). 
$251 \quad \mathbf{P}_{\mathbf{e}}=\frac{\left(\mathbf{P}-\mathbf{I}_{\mathbf{a}}\right)^{2}}{\left(\mathbf{P}-\mathbf{I}_{\mathbf{a}}\right)+\mathbf{S}}$

252 where:

$253 \mathrm{P}_{\mathrm{e}}=$ accumulated precipitation excess at time $\mathrm{t}$

$254 \mathrm{P}=$ accumulated rainfall depth at time $\mathrm{t}$

$255 \quad \mathrm{I}_{\mathrm{a}}=$ the initial abstraction (initial loss)

$256 \mathrm{~S}=$ potential maximum retention

$257 \quad \mathbf{I}_{\mathrm{a}}=\mathbf{0 . 2 S}$

$258 \quad \mathbf{P}_{\mathbf{e}}=\frac{(\mathbf{P}-\mathbf{0 . 2 S})^{2}}{(\mathbf{P}-\mathbf{0 . 8 S})+\mathbf{S}}$

259 where,

$260 \quad P \geq \mathbf{0 . 2 S}$

$261 \quad S=\frac{25400}{C N}-254$

262 The depression storage, interception and the infiltration during early stage of storm constitute the 263 initial abstraction $\left(\mathrm{I}_{\mathrm{a}}\right)$ (Ponce 1994). The imperviousness of the region controls the amount of initial 264 abstraction. More is the built-up percent, more is the imperviousness and less will be the amount of 265 initial abstraction and the impervious percent of each sub-basin was calculated by the percent of 266 LULC present (NRCS 1986; Garg et al. 2017). The sub-basin wise LULC percent statistics, depict 267 the high built percent in sub-basin W910 that clearly signifies its high impervious percent and 268 hence, less initial abstraction in this sub-basin (Fig.3.). The potential maximum retention is a 269 potential measure of basin for the extraction and retention of the storm precipitation depends on the

$270 \mathrm{CN}$. The mean $\mathrm{CN}$ value for each sub-basin was extracted from the $\mathrm{CN}$ raster grid as shown in the 271 Fig. 4. The CN raster was generated by the integration of soil (HSG), LULC and slope in the HEC- 
272 GeoHMS interface of Arc-GIS. The CN values of different LULC classes in HSG were taken from

273 the standard table called CN look up table as given in the Table 2 (NRCS 1986; Schwab et al. 2005).

274 HSG characterizes the soil types into four classes i.e., A, B, C, and D based on their hydrological

275 properties (runoff, infiltration, etc.), where D represents the soil having maximum surface runoff

276 and minimum infiltration capacity, $\mathrm{A}$ is the soil with minimum surface runoff and maximum

277 infiltration capacity, but C, and D, soil types lie in between A and D, respectively (NRCS 1986;

278 Subramanya 2008).

279

280 Fig. 3. LULC percent of each sub-basin

281

282 Table 2: CN values for different HSG group according to United States Department of Agriculture 283 (USDA) TR 55

285 The rainfall excess obtained from the loss model was transform into the surface runoff using the 286 SCS UH technique in the transform model (Feldman 2000; Reshma et al. 2010; Hari et al. 2011). 287 The mathematical formulation of SCS UH states that the peak of UH is a function of watershed 288 area and time of peak $\left(\mathrm{T}_{\mathrm{p}}\right)$. The time of peak depends on the excess precipitation and $\mathrm{T}_{\mathrm{lag}}$, whereas 289 the lag time is a function of time of concentration or travel time ( $\mathrm{T}_{\mathrm{c}}$ ) (NRCS 1986; Feldman 2000).

290 The TR-55 working sheet obtained during the configuration of model involves the calculation of $291 \mathrm{~T}_{\mathrm{c}}$. The $\mathrm{T}_{\mathrm{c}}$ of each sub-basin is the sum of travel time obtained during the sheet flow, shallow 292 concentrated flow and channel flow that depends on the basin physical characteristics. The details 293 of the watersheds characteristics involved in the TR-55 working sheet such as sheet flow 294 characteristics, shallow concentrated flow characteristics and channel flow characteristics are 
295 discussed in the USDA and National Resource Conservation Soil (NRCS) TR-55 technical release

296 (NRCS 1986). The DRH peak derived from the transform model was converted into the peak of

297 flood hydrograph using the base flow model. The base flow is the delayed sub-surface flow occurs

298 above the Ground Water Table (GWT) was estimated by Straight Line method (Subramanya 2008).

299 Muskingum Cunge and lag method were opted in routing model to derive the flood hydrograph at

300 the various sections of the reach (Feldman 2000; Subramanya 2008; Hari et al. 2011; ). Muskingum

301 Cunge method is a hydraulic method of routing which involves the continuity and the momentum

302 equation along with the equation of motion of unsteady flow i.e. St. Venant equation, whereas lag

303 method routes the flow with the $\mathrm{T}_{\text {lag }}$ provided in the specific reaches before the stations (Feldman

304 2000; Subramanya 2008; Reshma et al. 2010). $\mathrm{T}_{\text {lag }}$ is the time difference in the peak of rainfall and

305 peak of discharge of the event (or delay in the event peak flow) (Subramanya 2008).

306

307 Fig. 4. LULC, Soil, HSG and CN Map of Jhelum basin

308

$309 \quad$ 3.1.4 Construction of meteorological forcings and the simulation run

310 The meteorological forcing is one of the most important controlling indicators that governs the

311 hydrological model. The rainfall was acquired from IMD for the monsoon seasons (June-

312 September) of the year 1992, 1997, and 2014. The configured hydrological model was simulated

313 using constructed meteorological forcing for the calibration and validation. The current research

314 carried out simulations for the monsoon periods of the years 1992, 2014, and 1997 where, the model

315 calibration was done for the year 2014 and validation for the years 1992 and 1997, respectively.

316 The flood peaks discharges were estimated for each sub-basin using 2014 extreme rainfall as input

317 forcing. 


\subsection{Identification of vulnerable sub-basins using indicator-based GIS method}

320 This section includes the framework for spotting the vulnerable sub-basins. In order to locate such 321 sub-basins, the current framework is divided into two segments: 1) vulnerability approach, and

322 2) threshold selection criteria to classify the sub-basins into low and highly vulnerable.

\section{$324 \quad 3.2 .1$ Vulnerability approach}

325 It is the two-steps approach: 1) the estimation of normalized scores (0-1) of vulnerability 326 indicators and sub-indicators using the functional relationship (positive and negative) between

327 the vulnerability and their indicators, and 2) the computation of sub-basin wise vulnerability. 328 Normalization is the process of making quantities comparable to each other by making them 329 unitless and rescaling to the same range (in this case, $0-1$ ), since initially all the indicators have 330 different units and scale (Yoon 2012; Žurovec et al. 2017).

331 The present work had used an internationally recognized Human Development Index (HDI), 332 United Nation Development Program (UNDP's), 2006 (Birkmann 2006; Xs et al. 2006) min-max 333 linear transformation, a deductive approach for the computation of normalized scores of 334 vulnerability indicators and sub-indicators (Wu et.al. 2002; Yoon 2012; Cutter et.al. 2003). 335 Previous studies have also revealed the existence of this adopted methodology framework for the 336 assessment of vulnerable areas in the different scientific fields (Yoon 2012; Behanzin et al. 2016;

337 Kumar et al. 2016; Žurovec et al. 2017; Choudhary and Badal 2018). In this approach, the 338 functional relationship is based on the theoretical understandings only, where the positive and 339 negative relation signifies the direct and inverse relation (Wu et al. 2002; Cutter et al. 2003; Yoon 340 2012). In this case, sub-basins characteristics (terrain, hydrological, land use and soil) that have 
341 direct or inverse relation with the sub-basins flood peaks were treated as vulnerability indicators

342 to establish the functional relationship with the vulnerability. Since, more is the food peak, more

343 will be the sub-basins vulnerability. Further, these characteristics were classified into the sub-

344 characteristics that help in demonstrating a strong theoretical functional relationship

345 understanding with vulnerability than the previous one. Slope and elevation are terrain

346 characteristics have positive (or direct) relation with the flood peaks (Cunge 1969; NRCS 1986;

347 Subramanya 2008; Yalcin 2020). CN, Long Period Average (LPA) rainfall (1970-2015), peak

348 discharge (flood peaks at Sangam, RamMunshi Bagh and Asham are 10, 100 and 200 years return

349 period, respectively during Jhelum 2014 flood events) (Bhat et al. 2019) per unit area, and CN

350 belong to the hydrological characteristics have positive relation with flood peaks except $T_{c}$ that

351 has negative (or inverse) relation (NRCS 1986; Bosznay 1989; Ponce 1994; Stewart et al. 2012;).

352 Land Use characteristics such as BU, WB and GL/SI have positive relation with flood peaks

353 where EBF, CL, and WL/SL have negative relation that depends on the imperviousness of the

354 LULC ( Subramanya 2008; Brody et al. 2014; Sanyal et al. 2014; Garg et al. 2017; Mousavi and

355 Rostamzadeh 2019). For soil characteristics HSG A, B, C, and D were considered where A and

356 B have negative relation, but C and D have positive relation with the flood peaks (NRCS 1986; ;

357 Kim and Lee 2008; Stewart et al. 2012; Costache et al. 2020). Characteristics and sub358 characteristics of sub-basins and their relationships with the flood peaks are shown in Table 3.

359 Selection criteria for these characteristics were based on the data availability and the scientific

360 literature reviews (Subramanya 2008; D'Asaro and Grillone 2012; Sanyal et al. 2014; Yan et al.

361 2015; Abdulkareem et al. 2018; Jaafar et al. 2019; Mousavi and Rostamzadeh 2019; Sadek et al.

362 2020; Costache et al. 2020). 
364 Table 3: Basin characteristics and their relationship with peak runoff

366 HDI, UNDP's, 2006, mix-man linear normalization method for the positive and negative function

367 relationships of vulnerability indicators with vulnerability (Birkmann 2006; Xs et al. 2006; Yoon

368 2012) are discussed in the equations 5 and 6, respectively.

$369 \quad \mathbf{V}_{\mathbf{i j}}=\frac{\mathbf{X}_{\mathrm{ij}}-\operatorname{Min} \mathbf{X}_{\mathbf{i}}}{\operatorname{Max} \mathbf{X}_{\mathbf{i}}-\operatorname{Min} \mathbf{X}_{\mathbf{i}}}$

$370 \quad \mathbf{V}_{\mathrm{ij}}=\frac{\operatorname{Max} \mathbf{X}_{\mathbf{i}}-\mathbf{X}_{\mathrm{ij}}}{\operatorname{Max} \mathbf{X}_{\mathbf{i}}-\operatorname{Min} \mathbf{X}_{\mathbf{i}}}$

371 where,

$372 \mathbf{V}_{\mathbf{i j}}$ stands for the normalized vulnerability score regarding sub-indicators (i) for the sub-basins $373(\mathrm{j})$

$374 \mathbf{X}_{\mathbf{i j}}$ stands for the observed value of the same component for the same sub-basins;

$375 \operatorname{Max} \mathbf{X}_{\mathbf{i}}$ and $\mathbf{M i n} \mathbf{X}_{\mathbf{i}}$ stand for the maximum and minimum value of the observed range of values

376 of the same component for all the sub-basins.

377 The obtained normalized values of the sub-characteristics were averaged for each sub-basin to 378 obtain normalized score of the sub-basins characteristics as:

$379 \quad \mathbf{A I}=\frac{\sum_{\mathrm{i}}^{\mathrm{n}} \mathbf{x}_{\mathrm{ij}}}{\mathbf{N}}$

380 where,

381 AI being the average index of each sub-basin's vulnerability elements, $\mathbf{N}=$ the sum of the index 382 and $\mathbf{X}_{\mathbf{i j}}=$ the value of the index.

383 The overall Vulnerability Index (VI) scores (Fig.10) for each sub-basin was calculated by 384 weightage linear sum of sub-basins indicators:

$385 \quad \mathbf{V I}=\sum_{\mathbf{i}}^{\mathbf{n}} \mathbf{V}_{\mathbf{i}} \mathbf{W}_{\mathbf{i}}$ 
where,

$387 \quad \mathbf{V}_{\mathbf{i}}$ is the averaged normalized score of each basin's characteristics and $\mathbf{W}_{\mathbf{i}}$ is their weights used in 388 this research.

389 In this case, equal weightage $\left(\mathrm{W}_{\mathrm{i}}=0.25\right)$ were given to the basins characteristics to identify the 390 dominant basins characteristics also without any unfairness. Hence, the high averaged normalized

391 score values of the basin characteristics will represent their most dominant parameters influencing 392 their respective flood peaks. Higher the VI scores of sub-basins, the chance of their vulnerability 393 will be more (Birkmann 2006; Behanzin et al. 2016). The final obtained VI scores of the sub-basins 394 were used to produce the vulnerable sub-basin map (Fig.12a) using the Arc-GIS software by 395 converting the vector into polygon.

396 Identification of vulnerable districts (Fig.12b) were also done using the area percent contribution 397 of vulnerable sub-basins to each district and the calculated VI scores of respected districts shown 398 in the Table 7 and Fig. 13, respectively. The VI scores for each district $\left(\mathbf{V I}_{\mathbf{d}}\right)$ was calculated using 399 the area weightage method.

$400 \quad \mathbf{V I}_{\mathbf{d}}=\sum_{\mathrm{i}}^{\mathbf{n}} \mathbf{A}_{\mathbf{i}} \mathbf{V I}_{\mathbf{i}}$

401 where,

$402 \mathbf{A}_{\mathbf{i}}=$ area percent of low or highly vulnerable sub-basins of the respective district

$403 \quad \mathbf{V I}_{\mathbf{i}}=\mathrm{VI}$ scores of low or highly vulnerable sub-basins of the respective district

\section{$405 \quad$ 3.2.2 Threshold criteria}

406 The current section emphasized the methods adopted for deciding the threshold VI score to classify 407 the sub-basins between low and highly vulnerable. Present research has used three different 408 scientific techniques for this purpose such as: 1) Mean method, 2) Natural breaks (Jenks) method, 
409 and 3) Standard deviation method, respectively to find the Optimal Threshold Value (OTV) (Chung

410 and Lee 2009; Bhattacharya et al. 2020; Singh et al. 2020), a minimum value above which the

411 maximum of given regions become vulnerable. In this case, VI score (0.457) is considered as OTV

412 (derived from the standard deviation method), see Fig.11 for the classification of sub-basins into

413 low and highly vulnerable (Fig.12).

414 Mean method of finding OTV is the average of the all the obtained data values. But Jenks (1967)

415 natural breaks classification is the method for best arrangement of values into different classes

416 identifies the breakpoints by looking for groups and patterns inherent in the data(Ayalew 2004;

417 Stefanidis and Stathis 2013; Balasubramanian et al. 2017). It minimizes and maximizes the average

418 deviation of each class from the class mean and from the other groups means, respectively i.e.

419 minimize the variance within the class but maximize the variance between classes (Jenks, 1967).

420 Standard deviation method is based on the normal distribution signifies the extent of diversion of

421 attribute's values from mean of all the values that creates the class breaks with an equal proportion

422 of standard deviation generally one, one-half, one-third, and the one-fourth using the mean and

423 standard deviation from the mean (Stefanidis and Stathis 2013; Rahadianto et al. 2015).

424

\section{4. Results and discussion}

426 This section discusses the calibration and sensitivity of the hydrological model, validation of the 427 model and the identification of vulnerable sub-basins by relating their flood peak and selected 428 indicators.

429

$430 \quad$ 4.1 Calibration and validation of the hydrological model 
431 Calibration is the iterative process to estimate the optimized basin parameters for satisfactory

432 agreement between the simulated and observed data. But validation is a check that measures

433 accuracy of a calibrated model, closed to the real independent forcing's. In the present study, the

434 statistical parameters such as $\mathrm{R}^{2}$, RMSE, and NSE were used as the performance criteria for the 435 calibration and validation of the model.

\subsubsection{Model calibration and its sensitivity}

438 Automated method was adopted using the HEC-HMS model optimization technique (Feldman 439 2000) in order to calibrate the model. The model sensitivity (Fig.5a) towards the $\mathrm{CN}$ continues the 440 calibration process by an adjustment of $\mathrm{CN}$ scaling factor with an objective to maximize the NSE.

$441 \mathrm{CN}$ scaling factor is the fractional amount of change in the $\mathrm{CN}$ value. The surface runoff obtained 442 from the calibrated model has direct relationship with the $\mathrm{CN}$. The $0 \mathrm{CN}$ value means that all the 443 rain will infiltrate into the ground whereas $100 \mathrm{CN}$ value means all the rainfall will flow as the 444 surface runoff that signifies the ideal pavement condition. Ideally, the $\mathrm{CN}$ value cannot be greater 445 than 98, since the surface will hold some little amount of rainfall (Halwatura and Najim 2013).

446 In this study, optimization trial run was implemented at the Sangam gauging station for the duration 447 similar to model simulation run (Jun 2014 to Oct 2014), but the optimization objective run was 448 scheduled daily for the event period during Sep 3, 2014 to Sep 15, 2014 against the daily observed 449 available during that period only to derive the optimized $\mathrm{CN}$ scaling factor. Optimized $\mathrm{CN}$ scaling 450 factor was then adjusted to derive the maximum NSE for the whole period of model simulation run 451 (2014) to achieve the goal of calibration at the Sangam gauging station.

452 Fig.5a depicts sensitivity of the calibrated model with the maximum NSE value 0.989 obtained 453 against the final optimized $\mathrm{CN}$ scaling factor, 0.98 , governs the good efficiency of the model. 
454 Correlation coefficient $\left(\mathrm{R}^{2}\right)$ of calibrated model obtained at the Sangam gauging station is 0.9935

455 (Fig.5c) signifies the good fit and the calibration curve between the observed and the simulated.

457 Fig.5. Calibration (2014) at Sangam: a) Model Sensitivity, b) Time Series, and c) Scattered plot

459 Fig.5c shows that the slope (0.9908) of the regression line at the Sangam is less than one has the 460 minimal shift towards observed discharge with respect to the $45^{0}$ line, signifying that the model is 461 under predicting at Sangam. The calibrated peak flow simulated at the Sangam is $3425.90 \mathrm{~m}^{3} / \mathrm{s}$ 462 (Fig.5b) with -5.01 relative peak error percent. RMSE obtained for the calibrated model during the 463 linear regression at the Sangam gauging station is $106.53 \mathrm{~m}^{3} / \mathrm{s}$. Calibrated outflow from the Sangam 464 is now the inflow for the other stations such as RamMunshi Bagh and Asham in its downstream. $465 \mathrm{CN}$ of the sub-basins contributing to these two stations in the downstream are also optimized to 466 obtain the good fit and calibration curves (Fig.6a and 6b) between the observed and the simulated 467 at these sites. The maximum NSE obtained during this correlation process at the RamMunshi Bagh 468 and Asham is 0.8437 and $0.7368 . \mathrm{R}^{2}$ values 0.9588 and 0.9941 obtained during the correlation at 469 RamMunshi Bagh and Asham, respectively shows the good fit curve. Model is over predicting at 470 the RamMunshi Bagh and Asham since the shift in the regression line is towards the simulated one

471 from the $45^{0}$ line, having slopes (1.1481 and 1.2822) greater than 1. RMSE obtained at the 472 RamMunshi Bagh and Asham during the whole process of regression is $187.75 \mathrm{~m}^{3} / \mathrm{s}$ and 78.60 $473 \mathrm{~m}^{3} / \mathrm{s}$.

475 Fig.6. Scattered plots (2014) at other stations: a) RamMunshi Bagh and b) Asham 476 


\subsubsection{Diversion and attenuation of the flood peak}

478 This section enlightened the monitoring the capacity of reaches and the constructed Flood Spill 479 Channel (FSC). However, FSC starts at Reduced Distance (RD) $68.64 \mathrm{~km}$ Jhelum River and FSC 480 RD $0 \mathrm{~km}$ in between the Padshahi Bagh (RD $66.93 \mathrm{~km}$ Jhelum River) and RamMunshi Bagh (RD $481 \quad 71.70 \mathrm{~km}$ Jhelum River) gauging sites, respectively (Fig.2). While ends at the confluence point of 482 FSC and Ferozpora (Kuzer branch) Nallah at FSC RD $32.62 \mathrm{~km}$, respectively somewhere nearer to 483 the downstream of Asham gauging site (RD $106.10 \mathrm{~km})$, see Fig.2. The section also monitors the 484 cause of attenuated peaks observed during the 2014 flood events, either it is due to diversion from 485 FSC or due to the reduction in the capacity of FSC and reach or both. The diversion in peak 486 discharge was also observed during the Jhelum 2014 flood from the (FSC) situated between the 487 Padshahi Bagh (RD $66.93 \mathrm{~km})$ and RamMunshi Bagh $(71.70 \mathrm{~km})$ gauging sites. According to 488 Irrigation and flood control department, Kashmir the maximum observed diverted peak from the 489 FSC was $244 \mathrm{~m}^{3} / \mathrm{s}(8,600$ cusec $), 10.61 \%$ of peak at Padshahi Bagh $(2299$ cumec $)$ gives the current 490 capacity of the FSC during 2014 (Eptisa 2018; Romshoo et al. 2018). Diversion structure added

491 between the Padshahi Bagh and RamMunshi Bagh in the configured calibrated model simulated 492 the diverted peak flow as 223.16 cumec with relative percentage error $8.54 \%$ at the same capacity 493 of FSC observed during the 2014 flood. The details about the diversion from the FSC during the 494 Jhelum 2014 flood are discussed in the Table 4. During 2014, with respect to the inflow from the 495 Sangam (3262.61 Cumec), the maximum percentage of flow diverted from the FSC was also only 496 10.61\% (244 Cumec) of Padshahi Bagh. Maximum diversion in the peak flow observed from the 497 FSC with respect to the inflow from the Sangam (peak flow 1834.08 Cumec \& 1780.44 Cumec) 498 during the event years 1992 and 1997 were $36.81 \%$ \& $45.17 \%$. 
Table 4: Diversion of peak discharge during Jhelum 2014 flood

501

502 It was found that observed time lag (Fig.6.) in the peaks occurred at the gauging sites in the reach 503 during the Jhelum 2014 flood. Fig.6a. shows the approx. 11 hrs. (660 min) $\mathrm{T}_{\text {lag }}$ was observed at the 504 Sangam gauging location situated in the upstream of the Jhelum. Since, according to Central Water 505 Commission (CWC), the India Standard Time (IST) for starting the discharge data recording at the 506 gauging sites is 8:00 AM (CWC 2017), where 00:00 hrs. represent 12:00 AM. It was observed that 507 RamMunshi Bagh and Asham gauging sites have also $\mathrm{T}_{\text {lag }} 59$ hrs. (2 days 11 hrs.), and 75 hrs. (3 508 days 3 hrs.), respectively with respect to the Sangam as depicted in the Fig.6b. Tlag at Asham 509 gauging station with respect to the RamMunshi Bagh was observed as 18 hrs. (108 min), see Fig.6b.

510 The reduction in the outflow peaks at the gauging locations, called attenuation (Subramanya 2008)

511 were also found in this study during the Jhelum 2014 flood event. Table 5 shows the attenuations 512 observed in the peaks at the respective gauging stations during 2014 flood event. Total $37.02 \%$ and $513 \quad 34.41 \%$ attenuation in the peaks of outflow at RamMunshi Bagh and Asham were found, with 514 respect to their respective recorded inflows in their upstream. The outflow at Asham has 58.61\% 515 attenuation in its peak with respect to the inflow recorded at Sangam. Attenuation in the peak 516 discharge were also found in the observed flow during the event year 1992 at RamMunshi Bagh 517 and Asham by $36.81 \%$ and $0.55 \%$, respectively with respect to the inflows from their respective 518 upstream reaches, where 1152.49 Cumec measured at Asham. During the year 1997, the attenuated 519 peak was also observed at both RamMunshi Bagh (976.13 Cumec, 45.17\%) and Asham (824.30 520 Cumec, $15.55 \%)$.

522 Fig.7. a) Time lag (2014) at Sangam; b) flow (2014) at Sangam, RamMunshi Bagh \& Asham 
524 Table 5: Reach lag and attenuation in the outflow at the gauging stations during Jhelum 2014 flood

\subsubsection{Model validation}

527 The calibrated configured model is needed to be validated for checking the stability of the 528 calibrated model (Halwatura and Najim 2013). In the current research, the model was validated 529 at the Sangam gauging site (Sangam in the upstream has higher contribution percent in the flood 530 peaks than RamMunshi Bagh and Asham in the downstream, see Fig.11 and Table 6 and 7) for 531 the monsoon seasons of the years 1992 and 1997. Since during the monsoon period of selected 532 validation years, the valley has also experienced the extreme flood events (Romshoo et al. 2018), 533 see Fig.8. The statistical analysis of model validation results (see Fig.9) that manifest the good 534 agreement of the calibrated model in predicting the real scenario in the studied basin. Correlation 535 coefficient values obtained 0.9618 and 0.9486 exhibit good linear fitting of regression line during 536 the years 1992 and 1997. Obtained slope values 0.9882 and 1.0210 for the years 1992 and 1997

537 show the shifting of regression line towards the observed and simulated, respectively. Also, the 538 RMSE obtained for the regression analysis are 86.39 Cumec and 79.64 Cumec, respectively.

540 Fig.8. Year wise maximum flow at Sangam

542 Fig.9.Validation scattered plots at Sangam: a) year 1992 and b) year 1997 
545 The present section of the results and discussion highlights the vulnerable sub-basins that have

546 significant contribution to their flood peaks. The most dominant indicators of such sub-basins

547 influencing their flood peaks were also identified during the recognition process of these sub-basins

548 of the Jhelum River. The normalized scores of the basin characteristics and the VI score obtained

549 for each sub-basin are shown in Fig.10. It is observed that W810 (VI score - 0.645) and W950 (VI

550 score - 0.325) sub-basins are the most and the least vulnerable (Fig.12a and Table 6) sub-basins of

551 the Jhelum river contributing to the Sangam and RamMunshi Bagh gauging sites situated in the

552 upstream and downstream, respectively.

553

554 Fig.10. Sub-basins wise Vulnerability Index score plot with their classification using the color ramp 555 representation and the normalized score plot of their characteristics

557 Fig.11. D/S = Downstream (contributing to RamMunshi Bagh and Asham) and U/S = Upstream 558 (contributing to Sangam)

560 The sub-basins which has VI score below the obtained OTV 0.457, see Fig.11 were categorized as 561 highly vulnerable sub-basins that contributing significantly to their peak flood (Table 6). The OTV 562 for this classification was considered using the standard deviation classification method. Since, 563 among all the three adopted methods (mean, natural breaks, and standard deviation) for the OTV 564 selection, the standard deviation has minimum value and classify the maximum number sub-basins 565 of Jhelum river basin into the vulnerable category. All the highly vulnerable sub-basins of this 566 basin have benefaction to the Sangam gauging site situated in the upstream of the river except the 567 W610 which is contributing the Asham gauging station in the downstream the river. The most 
568 influencing characteristics of such sub-basins belong to their respective gauging sites are discussed

569 in the Table 6. The hydrological characteristics (averaged normalized score -0.844 ) have

570 dominated over the terrain, soil and LULC characteristics in case of most vulnerable sub-basin

571 W810. W810 has the lowest $\mathrm{T}_{\mathrm{c}}(3.66 \mathrm{hrs})$, highest LPA $(1076.63 \mathrm{~mm})$, low area $\left(228.07 \mathrm{Km}^{2}\right)$ and

572 high CN (76) comparison to the all other sub-basins signify its most vulnerable condition. Romshoo

573 et al. (2018) have also stated that the lower Tc and high slope gradients of sub-basins in the upstream

574 sides contributing to the Sangam are the indicators responsible for Jhelum 2014 flood event. The

575 lower $T_{c}$ means the time required by the river flows to reach their respective junction will be very

576 low (Subramanya 2008). However, the dominant parameters of other highly vulnerable sub-basins

577 include the soil and terrain characteristics as well except LULC parameters. Fig.11 represents the

578 final map of the vulnerable sub-basins of Jhelum River stretched between maximum and minimum

579 VI scores 0.644 and 0.325 , respectively depicts the high and the low vulnerable sub-basins.

581 Table 6: Sub-basins contributing significantly to the flood peak flows and their most dominant 582 influencing parameters

584 Fig.12. Vulnerability Index score map: a) sub-basins wise, and b) district wise

586 Fig.12b depicts the low and highly vulnerable sub-basins located in the respective districts.

587 Anantnag district has the largest area $\left(2725.738 \mathrm{Km}^{2}\right)$ amongst the all other districts covering 588 only the highly vulnerable sub-basins (100\%) namely, W610, W700, W810, W1020, W1090, and 589 W1130, respectively (Table 7 and Fig.13), place it in the category of highly vulnerable. Like the 590 Anantnag district, Ganderbal, Kulgam and the part of Ramban are also 100\% covering the only 
591 highly vulnerable sub-basins as shown in the table 7 and Fig.13 made them highly vulnerable 592 districts. However, the Shupiyan district has both low (49.17\%) and highly (50.83\%) vulnerable 593 sub-basins where the contribution of highly vulnerable is more that made the district highly 594 vulnerable. But, the VI score obtained for the district using the equation 9 as shown in Fig. 13 has 595 made the Kulgam, the most vulnerable district and the Badgam as the least vulnerable. Badgam 596 and part of Baramulla have $100 \%$ contribution of only low vulnerable sub-basins however 597 Pulwama and Srinagar have both low and highly vulnerable sub-basins area covering where the 598 area percentage of low vulnerable sub-basins are high. The districts are also categorized into the 599 downstream (Badgam, part of Baramulla, Pulwama, Srinagar, and Ganderbal) and upstream 600 (Shupiyan, part of Ramban, Anantnag and Kulgam) parts, see Fig.13 based on the respective area 601 percentage of sub-basins (located in the upstream and downstream) in the districts for the easy 602 acquirement of information. Present study have used the indicator based approach for 603 vulnerability assessment using the indicators based on hydrological aspects of basin only.

604 However, the results may vary due to the use of only socio-economic indicators in this 605 vulnerability assessment. Hence, the integrated uses of hydrology and socio-economic based 606 indicators can be used for the future research in this field.

608 Table 7: Analysis of districts corresponds to the low and highly vulnerable sub-basins 609

610 Fig.13. Area contribution of sub-basins in the respective districts and district wise VI score 611

\section{5. Conclusion}


613 A novel approach using hydrological model and indicator-based GIS method for sub-basin level

614 flood peak and vulnerability assessment has been proposed in this study.

615 1. The sub-basins W810 (Fig.2 and Fig.12b), part of Anantnag district, contributing to the Sangam 616 gauging site, is found to be the most vulnerable among the all other sub-basins, see Fig.12a.

617 The peak discharge of this basin was controlled by hydrological characteristics compared to 618 other characteristics (e.g. terrain, soil; Table 6).

619 2. Various districts such as Shupiyan, Ganderbal, Anantnag, part of Rambana and Kulgam are 620 falling under highly vulnerable category. However, Anantnag district $\left(2725.738 \mathrm{Km}^{2}\right)$ acquires 621 the largest part of the highly vulnerable region of the Jhelum river basin, see Fig. 12b and Table 6227.

623 3. It was found that $50 \%$ sub-basins falling in highly vulnerable category are contributing to the 624 accumulated flow of Sangam station making upstream side of Jhelum River more vulnerable 625 than the downstream side (Table 6 and 7).

626 4. Attenuation in the observed peak outflows were also observed during 2014 flood event due to 627 reduction in the carrying capacity of river channel and FSC (Table 4 and 5). The overflow of 628 discharge during that flood duration has caused the inundation in the regions surrounding to the 629 Jhelum River. The flood inundation for that flooded period was mapped by Bhatt et al. (2017) 630 using the Remote Sensing satellite data.The decrement in the capacity of the reach and the FSC 631 were due the siltation and accumulation of sediments carried by the regular and the heavy flood 632 flows.

633 5. These vulnerable sub-basins and the sub-basins with low Tc are needed to take care by the 634 flood management authorities to prevent the region from such type of flood events in the future. 
635 It is recommended to monitor the sediment flows along with the discharge on the regular basis in

636 the channel and the FSC to avoid the 2014 flood events like situation in the future. Authorities

637 should maintain (dredging for removing sediments) the existing FSCs and river channel regularly

638 and increase the number of FSCs especially in the downstream of Sangam to increase the capacity

639 of existing FSCs. In order to increase mitigation time during and before the extreme flood events,

640 the increment in $T_{c}$ of highly vulnerable sub-basins is advised through sustainable watershed

641 management. It is recommended to use AI-based models and their hybrids in the future studies to

642 improvise the results of hydrological predictions.

\section{Acknowledgement}

645 Our heartfelt thanks to Irrigation and flood control department, Kashmir and India Metrological 646 Department for providing the discharge and rainfall data. We are also thankful to Director, Indian

647 Institute of Remote Sensing, ISRO, Dehradun and Disaster Management Support (DMS) office of

648 ISRO headquarters for their help, support and motivation during this entire research. This work was

649 done as part of ISRO sponsored DMS (research and development) project "Remote sensing, ground

650 observations and integrated modelling based early warning system for climatic extremes of North

651 West Himalayan region."

652

653 Conflicts of interest/ Competing interest

654 The authors declare that they have no known competing financial interests or personal relationships

655 that could have appeared to influence the work reported in this paper.

\section{Availability of data and material}


658 The data that support the findings of this study are available from the corresponding author Pankaj

659 R. Dhote, upon reasonable request.

660

661 Code availability

662 Not applicable.

663

664 Authors' contributions

665 RR:Conceptualization, analysis and prepared original draft; PRD: Conceptualization, analysis and

666 wrote paper; PKT: Reviewed paper and helped in producing figurers; SPA: Supervision and 667 reviewed paper

668

669

\section{References}

670 Abdulkareem, J.H., Sulaiman, W.N.A., Pradhan, B., and Jamil, N.R., 2018. Relationship

671 between design floods and land use land cover (LULC) changes in a tropical complex

672 catchment. Arab J Geosci, 11 (14), 1-17. https://doi.org/10.1007/s12517-018-3702-4.

673 Abushandi, E. and Merkel, B., 2013. Modelling rainfall runoff relations using HEC-HMS and

674 IHACRES for a single rain event in an arid region of Jordan. Water Resour Manage, 27(7),

675 2391-2409. https://doi.org/10.1007/s11269-013-0293-4..

676 Aggarwal S.P., Garg V., Thakur P.K., Nikam B.R., 2019. Hydrological Modelling in North

677 Western Himalaya. In: Navalgund R., Kumar A., Nandy S. (eds). Remote Sensing of

678 Northwest Himalayan Ecosystems. Springer, Singapore. https://doi.org/10.1007/978-981-

679 13-2128-3_6.

680 Ahmad, T., Pandey, A.C., and Kumar, A., 2018a. Flood hazard vulnerability assessment in 
Kashmir Valley, India using geospatial approach. Phy Chem Earth, Parts A/B/C, 105, 5971. https://doi.org/10.1016/j.pce.2018.02.003.

684 Álvarez, C., Juanes, J. a., García, A., Sainz, A., Puente, A., and Revilla, J. a., 2008. Surface water resources assessment in scarcely gauged basins in the north of Spain. J Hydrol, 356(3-4), 312-326. https://doi.org/10.1016/j.jhydrol.2008.04.019.

Ayalew, L., Yamagishi, H. and Ugawa, N., 2004. Landslide susceptibility mapping using GISbased weighted linear combination, the case in Tsugawa area of Agano River, Niigata Prefecture, Japan. Landslides, 1(1), 73-81. https://doi.org/10.1007/s10346-003-0006-9.

Balasubramanian, A., Duraisamy, K., Thirumalaisamy, S., Krishnaraj, S., and Yatheendradasan, R.K., 2017. Prioritization of subwatersheds based on quantitative morphometric analysis in lower Bhavani basin, Tamil Nadu, India using DEM and GIS techniques. Arab J Geosci,

Behanzin, D.I., Thiel, M., Szarzynski, J., and Boko, M., 2016. GIS-Based Mapping of Flood Vulnerability and Risk in the Bénin Niger River Valley. Int J Geomat Geosci, 6 (3), 1653-

Beyene, T., Lettenmaier, D.P., and Kabat, P., 2010. Hydrologic impacts of climate change on the Nile River Basin: Implications of the 2007 IPCC scenarios. Climatic Change, 100 (3),

Bhat, M.S., Alam, A., Ahmad, B., Kotlia, B.S., Farooq, H., Taloor, A.K., and Ahmad, S., 2019. 433-461. https://doi.org/10.1007/s10584-009-9693-0. Flood frequency analysis of river Jhelum in Kashmir basin. Quatern Int, 507, 288-294. https://doi.org/10.1016/j.quaint.2018.09.039.

Bhatt, C.M., Rao, G.S., Farooq, M., Manjusree, P., Shukla, A., Sharma, S.V.S.P., Kulkarni, 

Manjusree, P., and Shukla, A., 2017. Satellite-based assessment of the catastrophic Jhelum floods of September 2014 , Jammu \& Kashmir , India. Geomat Nat Haz Risk, 8 (2), 309327. https://doi.org/10.1080/19475705.2016.1218943.

Bhattacharya, R.K., Chatterjee, N. Das, and Das, K., 2020. Sub-basin prioritization for assessment of soil erosion susceptibility in Kangsabati, a plateau basin: A comparison

Bhutiyani, M.R., Kale, V.S., and Pawar, N.J., 2010. Climate change and the precipitation variations in the northwestern Himalaya: 1866-2006. Int J Climatol: J R Meteorol Soc, 30

Bilham, R., Bali, B.S., Bhat, M.I. and Hough, S., 2010. Historical earthquakes in Srinagar,

Birkmann, J., 2006. Measuring vulnerability to promote disaster-resilient societies: Conceptual 
139-144. https://doi.org/10.1061/(ASCE)0733-9437(1989)115:1(139).

728 Brody, S., Blessing, R., Sebastian, A., and Bedient, P., 2014. Examining the impact of land 729 use/land cover characteristics on flood losses. J Environ Plan Manag, 57 (8), 1252-1265.

$730 \quad$ https://doi.org/10.1080/09640568.2013.802228

731 Census of India, 2011 provisional population totals. New Delhi: Office of the Registrar General 732 and Census Commissioner..

733 Chang, T.K., Talei, A., Alaghmand, S., and Ooi, M.P.L., 2017. Choice of rainfall inputs for 734 event-based rainfall-runoff modeling in a catchment with multiple rainfall stations using 735 data-driven techniques. J Hydrol, 545, 100-108.

736 https://doi.org/10.1016/j.jhydrol.2016.12.024.

737 Chaponnière, A., Boulet, G., Chehbouni, A., and Aresmouk, M., 2008. Understanding 738 hydrological processes with scarce data in a mountain environment. HydrolProcess, 22 739 (12), 1908-1921. https://doi.org/10.1002/hyp.6775.

740 Chen, H., Ito, Y., Sawamukai, M., and Tokunaga, T., 2015. Flood hazard assessment in the 741 Kujukuri Plain of Chiba Prefecture, Japan, based on GIS and multicriteria decision 742 analysis. Nat Haz, 78 (1), 105-120. https://doi.org/10.1007/s11069-015-1699-5.

743 Choudhary, H. and Badal, P.S., 2018. Assessing Climate Change Impacts and Vulnerability

744 Indices in Regions of Eastern Uttar Pradesh. Indian J Eco Dev, 14 (1a), 18-22. 745 http://dx.doi.org/10.5958/2322-0430.2018.00029.X.

746 Chouksey, A., Lambey, V., Nikam, B.R., Aggarwal, S.P. and Dutta, S., 2017. Hydrological 747 modelling using a rainfall simulator over an experimental hillslope plot. Hydrology, 4(1), 748 17. https://doi.org/10.3390/hydrology4010017.

749 Chung, E.-S. and Lee, K.S., 2009. Prioritization of water management for sustainability using 
hydrologic simulation model and multicriteria decision making techniques. J Environ Manage, 90 (3), 1502-1511. https://doi.org/10.1016/j.jenvman.2008.10.008.

752 Clark, G.E., Moser, S.C., Ratick, S.J., Dow, K., Meyer, W.B., Emani, S., Jin, W., Kasperson, 753 J.X., Kasperson, R.E., and Schwarz, H.E., 1998. Assessing the vulnerability of coastal 754 communities to extreme storms: the case of Revere, MA., USA. Mitigation and adaptation 755 strategies for global change, 3 (1), 59-82.

756 Costache, R., Țîncu, R., Elkhrachy, I., Pham, Q.B., Popa, M.C., Diaconu, D.C., Avand, M., 757 Costache, I., Arabameri, A., and Bui, D.T., 2020. New neural fuzzy-based machine 758 learning ensemble for enhancing the prediction accuracy of flood susceptibility mapping. 759 Hydrolog Sci J, 65 (16), 2816-2837. https://doi.org/10.1080/02626667.2020.1842412.

760 Cunge, J.A., 1969. On the subject of a flood propagation computation method (Musklngum 761 method). J Hydraul Res, 7 (2), 205-230. https://doi.org/10.1080/00221686909500264.

762 Cutter, S.L., Boruff, B.J., and Shirley, W.L., 2003. Social vulnerability to environmental 763 hazards. Social science quarterly, 84 (2), 242-261.

764 CWC. 2017. Handbook for Hydrometeorological Observations. Ministry of Water Resources, 765 River Development and Ganga Rejuvenation, Government of India. 766 http://www.cwc.gov.in/sites/default/files/final-hm-handbook-jan-2017.pdf. $767 \quad$

768 D'Asaro, F. and Grillone, G., 2012. Empirical investigation of curve number method parameters 769 in the Mediterranean area. J Hydrol Eng, 17 (10), 1141-1152.

770 https://doi.org/10.1061/(ASCE)HE.1943-5584.0000570.

771 Dar, R.A., Chandra, R., Romshoo, S.A., Lone, M.A., and Ahmad, S.M., 2015. Isotopic and 772 micromorphological studies of Late Quaternary loess-paleosol sequences of the Karewa 
Group: inferences for palaeoclimate of Kashmir Valley. Quatern Int, 371, 122-134. https://doi.org/10.1016/j.quaint.2014.10.060.

775

776

777

778

779

780

781

782

783

784

785

786

787

788

789

790

791

792

793

794

795

Dhar, O.N., Mandal, B.N., and Kulkarni, A.K., 1982. Effect of the Pir Panjal range of Himalayas over monsoon rainfall distribution in Kashmir Valley. In: Proc. Int. Symp. hydrological aspects of mountainous watersheds.

Dhar, O.N. and Nandargi, S., 2003. Hydrometeorological aspects of floods in India. Nat Haz, 28 (1), 1-33. https://doi.org/10.1023/A:1021199714487.

Dhar, O.N. and Nandargi, S., 2005. Distribution of precipitation over the Himalayas. J Met, 30, 83-91.

Dhote, P. R., Thakur, P. K., Aggarwal, S. P., Sharma, V. C., Garg, V., Nikam, B. R., and Chouksey, A., 2018. Experimental Flood Early Warning System In Parts of Beas Basin Using Integration of Weather Forecasting, Hydrological and Hydrodynamic Models. Int Arch Photogramm Remote Sens Spatial Inf Sci, XLII-5, 221-225. https://doi.org/10.5194/isprs-archives-XLII-5-221-2018.

Dhote, P.R., Aggarwal, S.P., Thakur, P.K. and Garg, Vaibhav, 2019. Flood inundation prediction for extreme flood events: a case study of Tirthan River, North West Himalaya. Himal Geol, 40(2), 128-140.Ebi, K.L., Woodruff, R., Von Hildebrand, A., and Corvalan, C., 2007. Climate change-related health impacts in the Hindu Kush-Himalayas. EcoHealth, 4 (3), 264-270. https://doi.org/10.1007/s10393-007-0119-z.

Engineers, U.S. Army Corps, 2008. Hydrologic modeling system (HEC-HMS) application guide: version 3.1. 0. Institute for Water Resources, Davis.

Eptisa, 2018. Jhelum and Tawi Flood Recovery Project. The World Bank. http://jtfrp.in/wpcontent/uploads/2019/03/Task1_Report_Final.pdf. 
ESRI, 2011. Release 10.2.1. Redlands, CA: Environmental Systems Research Institute.

797 Falah, F., Rahmati, O., Rostami, M., Ahmadisharaf, E., Daliakopoulos, I.N., and Pourghasemi, 798 H.R., 2019. Artificial Neural Networks for Flood Susceptibility Mapping in Data-Scarce Urban Areas. Spatial Model in GIS and R for Earth Environ Sci (323-336). Elsevier Inc.

801 Feldman, A.D., 2000a. Hydrologic Modeling System HEC-HMS technical reference manual: US Army Corps of Engineers. Hydrologic Engineering Center (609 Second St., Davis, CA

Feldman, A.D., 2000b. Hydrologic modeling system HEC-HMS: technical reference manual.

Ganjoo, R.K., 2014. The Vale of Kashmir: Landform Evolution and Processes BT- Landscapes

and Landforms of India. In: Kale V. (eds) Landscapes and Landforms of India. World US Army Corps of Engineers, Hydrologic Engineering Center.

Ganjoo, R.K., 2014. The Vale of Kashmir: Landform Evolution and Pry

Geomorphological Landscapes, , 125-133. Springer, Dordrecht.

https://doi.org/10.1007/978-94-017-8029-2_11.

Ganju, A. and Dimri, A.P., 2004. Prevention and Mitigation of Avalanche Disasters in Western

Himalayan Region. NatHaz, 31 (2), 357-371.

https://doi.org/10.1023/B:NHAZ.0000023357.37850.aa.

Garg, V., Aggarwal, S.P., Gupta, P.K., Nikam, B.R., Thakur, P.K., Srivastav, S.K. and Kumar,

818 Halwatura, D. and Najim, M.M.M., 2013. Application of the HEC-HMS model for runoff 
simulation in a tropical catchment. Environ Modell Softw, 46, 155-162. https://doi.org/10.1016/j.envsoft.2013.03.006.

821 Hari, K., Durga, V., Rao, V.V., and Dadhwal, V.K., 2011. A Distributed Model for Real-Time 822 Flood Forecasting in the Godavari Basin Using Space Inputs. Int J Disaster Risk Sci, 2 (3), 823 31-40. https://doi.org/10.1007/s13753-011-0014-7.

824 He, Z., Wen, X., Liu, H., and Du, J., 2014. A comparative study of artificial neural network, 825 adaptive neuro fuzzy inference system and support vector machine for forecasting river flow in the semiarid mountain region. J Hydrol, 509, 379-386.

Hong, H., Panahi, M., Shirzadi, A., Ma, T., Liu, J., Zhu, A.X., Chen, W., Kougias, I., and Kazakis, N., 2018. Flood susceptibility assessment in Hengfeng area coupling adaptive

Huang, L., Liu, X., Liu, Y., Lang, B., and Tao, D., 2017. Centered weight normalization in accelerating training of deep neural networks. In: Proceedings of the IEEE International

Hunukumbura, P.B., Weerakoon, S.B. and Herath, S., 2008. Runoff modeling in the upper

836 Kotmale Basin. Traversing No Man's Land, Interdisciplinary Essays in Honor of Professor 837 Madduma Bandara. University of Peradeniya, Sri Lanka, 169-184. Ibrahim-Bathis, K. and Ahmed, S.A., 2016. Rainfall-runoff modelling of Doddahalla watershed—an application of HEC-HMS and SCN-CN in ungauged agricultural watershed. Arab J Geosci, 9 (3), 170. https://doi.org/10.1007/s12517-015-2228-2.

Ives, J.D., 2004. Himalayan Perceptions: Environmental change and the well-being of mountain 
peoples(Vol. 6). Routledge, Taylor and Francis Group.

843 Jaafar, H.H., Ahmad, F.A., and El Beyrouthy, N., 2019. GCN250, new global gridded curve

844 numbers for hydrologic modeling and design. Sci Data, 6 (1), 1-9.

845 https://doi.org/10.1038/s41597-019-0155-X.

846 Jenks, G.F., 1967. The data model concept in statistical mapping. International yearbook of

847 cartography, 7, 186-190.

848 Jenson, S.K. and Domingue, J.O., 1988. Extracting topographic structure from digital elevation

849 data for geographic information system analysis. Photogrammetric engineering and remote

$850 \quad$ sensing, $54(11), 1593-1600$.

851 Jonkman, S.N., 2005. Global perspectives on loss of human life caused by floods. Nat Haz, 34

852 (2), 151-175. https://doi.org/10.1007/s11069-004-8891-3.

853 Keshari, A.K., Satapathy, D.P. and Kumar, A., 2010. The influence of vertical density and

854 velocity distributions on snow avalanche runout. Annals of glaciology, 51(54), 200-206.

855 https://doi.org/10.3189/172756410791386409.

856 Kim, N.W. and Lee, J., 2008. Temporally weighted average curve number method for daily

857 runoff simulation. Hydrol Process: IntJ, 22 (25), 4936-4948.

858 https://doi.org/10.1002/hyp.7116.

859 Koneti, S., Sunkara, S.L., and Roy, P.S., 2018. Hydrological Modeling with Respect to Impact

860 of Land-Use and Land-Cover Change on the Runoff Dynamics in Godavari River Basin

861 Using the HEC-HMS Model. ISPRS Int J of Geo-Inf, 7(6), 206.

862 https://doi.org/10.3390/ijgi7060206.

863 Kumar, R. and Acharya, P., 2016. Flood hazard and risk assessment of 2014 floods in Kashmir

864 Valley : a space-based multisensor approach. Nat Haz, 84 (1), 437-464. 

https://doi.org/10.1007/s11069-016-2428-4.

866 Kumar, S., Raizada, A., Biswas, H., Srinivas, S., and Mondal, B., 2016. Assessment of 867 vulnerability to climate change: A case study of Karnataka. Indian J of Soil Conservation, $868 \quad 44(3), 314-320$.

869 Lawrence, S.W.R., 1895. The Valley of Kashmir. Asian Education Services, New Delhi.

870 Li, Y., Grimaldi, S., Walker, J.P., and Pauwels, V.R.N., 2016. Application of remote sensing 871 data to constrain operational rainfall-driven flood forecasting: A review. Remote Sensing, 8 (6), 456. https://doi.org/10.3390/rs8060456.

Loukas, A. and Vasiliades, L., 2014. Streamflow simulation methods for ungauged and poorly gauged watersheds. Nat Haz Earth Syst Sci, 14 (7), 1641-1661. https://doi.org/10.5194/nhess-14-1641-2014.

Maqsood, S.T., Schwarz, J., 2010. Comparison of Seismic Vulnerability of Buildings before and after 2005 Kashmir Earthquake. Seismological Research Letters, 81 (1), 85-98. https://doi.org/10.1785/gssrl.81.1.85.

Mehdizadeh, S., Fathian, F., and Adamowski, J.F., 2019. Hybrid artificial intelligence-time series models for monthly streamflow modeling. Applied Soft Computing, 80, 873-887. https://doi.org/10.1016/j.asoc.2019.03.046.

Meraj, G., Romshoo, S.A., R. Yousuf, A., Altaf, S., and Altaf, F., 2015. Assessing the influence of watershed characteristics on the flood vulnerability of Jhelum basin in Kashmir Himalaya. Nat Haz, 77(1), 153-175. https://doi.org/10.1007/s11069-015-1605-1.

Milewski, A., Sultan, M., Yan, E., Becker, R., Abdeldayem, A., Soliman, F., and Gelil, K.A., 2009. A remote sensing solution for estimating runoff and recharge in arid environments. J Hydrol, 373 (1-2), 1-14. https://doi.org/10.1016/j.jhydrol.2009.04.002. 
Mishra, A. and Srinivasan, J., 2013. Did a cloud burst occur in Kedarnath during 16 and 17 June 2013? Current Science, 105 (10), 1351-1352.

Mishra, S.K., Jain, M.K., and Singh, V.P., 2004. Evaluation of the SCS-CN-based model incorporating antecedent moisture. Water Resour Manag, 18 (6), 567-589. https://doi.org/10.1007/s11269-004-8765-1.

Miyato, T., Kataoka, T., Koyama, M., and Yoshida, Y., 2018. Spectral normalization for generative adversarial networks. arXiv preprint arXiv:1802.05957.

Mousavi, S.M. and Rostamzadeh, H., 2019. Estimation of flood land use/land cover mapping by regional modelling of flood hazard at sub-basin level case study: Marand basin. Geomat Nat Haz Risk, 10(1), 1155-1175. https://doi.org/10.1080/19475705.2018.1549112.

Morid, S., Gosain, A.K. and Keshari, A.K., 2002, July. Comparison of the SWAT model and ANN for daily simulation of runoff in snowbound ungauged catchments. In Fifth international conference on hydroinformatics, Cardiff, UK.

Murari, L., Nozawa, T., Emori, S., Harasawa, H., Takahashi, K., Kimoto, M., Abe-Ouchi, A., Nakajima, T., Takemura, T., and Numaguti, A., 2001. Future climate change: Implications for Indian summer monsoon and its variability. Current Science, 81 (9), 1196-1207.

Nandargi, S. and Dhar, O.N., 2011. Extreme rainfall events over the Himalayas between 1871 and 2007. Hydrolog Sci J, 56 (6), 930-945. https://doi.org/10.1080/02626667.2011.595373.

Nasiri, H., Yusof, M.J.M., and Ali, T.A.M., 2016. An overview to flood vulnerability assessment methods. Sustain Water Resour Manag 2 (3), 331-336. https://doi.org/10.1007/s40899-016-0051-x.

Nikam, B.R., Garg, V., Jeyaprakash, K., Gupta, P.K., Srivastav, S.K., Thakur, P.K. and 
Aggarwal, S.P., 2018. Analyzing future water availability and hydrological extremes in the Krishna basin under changing climatic conditions. Arab J Geosci, 11(19), 1-16. https://doi.org/10.1007/s12517-018-3936-1.

914 Nourani, V., Kisi, Ö., and Komasi, M., 2011. Two hybrid artificial intelligence approaches for 915 modeling rainfall-runoff process. J Hydrol, 402 (1-2), 41-59.

916 https://doi.org/10.1016/j.jhydrol.2011.03.002.

917 NRCS, U., 1986. Urban Hydrology for Small Watersheds (TR-55). Engineering Division, Soil 918 Conservation Service, US Department of Agriculture.

919 Parry, M., Parry, M.L., Canziani, O., Palutikof, J., Van der Linden, P. and Hanson, C. eds., 920 2007. Climate change 2007-impacts, adaptation and vulnerability: Working group II 921 contribution to the fourth assessment report of the IPCC (Vol. 4). Cambridge University Press.Planning Commission, 2011. Report of working group on flood management and

930 on Bengawan Solo River basin flood prone areas using analytic hierarchy process and

931 natural breaks: Study case: East Java. In 2015 International Conference on Data and

932 Software Engineering (ICoDSE) (195-200). IEEE.

933 https://doi.org/10.1109/ICODSE.2015.7436997. 
934 Ray, P.K.C., Parvaiz, I., Jayangondaperumal, R., Thakur, V.C., Dadhwal, V.K., and Bhat, F.A., 935 2009. Analysis of seismicity-induced landslides due to the 8 October 2005 earthquake in $936 \quad$ Kashmir Himalaya. Current Science, 97 (12), 1742-1751.

937 Razmkhah, H., Saghafian, B., Ali, A.-M.A., and Radmanesh, F., 2016a. Rainfall-runoff 938 modeling considering soil moisture accounting algorithm, case study: Karoon III River 939 basin. Water Resour, 43 (4), 699-710. https://doi.org/10.1134/S0097807816040072. 940 Razmkhah, H., 2016b. Comparing performance of different loss methods in rainfall-runoff 941 modeling. Water Resour, 43 (1), 207-224. https://doi.org/10.1134/S0097807816120058.

942 Reshma, T., Kumar, P.S., Babu, M.J.R.K., and Kumar, K.S., 2010. Simulation of runoff in 943 watersheds using SCS-CN and muskingum-cunge methods using remote sensing and 944 geographical information systems. Int J Adv SciTech, 25 (31).

945 Romshoo, S.A., Altaf, S., Rashid, I., and Ahmad Dar, R., 2018. Climatic, geomorphic and 946 anthropogenic drivers of the 2014 extreme flooding in the Jhelum basin of Kashmir, India. 947 Geomat Nat Haz Risk, 9 (1), 224-248. https://doi.org/10.1080/19475705.2017.1417332.

948 Romshoo, S.A., Bhat, S.A., and Rashid, I., 2012. Geoinformatics for assessing the 949 morphometric control on hydrological response at watershed scale in the upper Indus 950 Basin. J Earth Syst Sci, 121 (3), 659-686. https://doi.org/10.1007/s12040-012-0192-8.

951 Sadek, M., Li, X., Mostafa, E., Freeshah, M., Kamal, A., Sidi Almouctar, M.A., Zhao, F. and 952 Mustafa, E.K., 2020. Low-cost solutions for assessment of flash flood impacts using 953 Sentinel-1/2 data fusion and hydrologic/hydraulic modeling: Wadi El-Natrun Region, 954 Egypt. Advances in Civil Engineering, 2020. https://doi.org/10.1155/2020/1039309. 955 Sanyal, J., Densmore, A.L., and Carbonneau, P., 2014. Analysing the effect of land956 use/cover changes at sub-catchment levels on downstream flood peaks: A semi-distributed 
modelling approach with sparse data. Catena, 118, 28-40. https://doi.org/10.1016/j.catena.2014.01.015.

959 Scharffenberg, W.A. and Fleming, M.J., 2006. Hydrologic modeling system HEC-HMS: user's 960 manual. US Army Corps of Engineers, Hydrologic Engineering Center.

961 Schwab, G.O., Fangmeier, D.D., Elliot, W.J., and Frevert, R.K., 2005. Soil and Water

962 Conservation Engineering. fourth. New york: Jhon Wiley and Sons.

963 Shamseldin, A.Y., O’Connor, K.M., and Nasr, A.E., 2007. A comparative study of three neural 964 network forecast combination methods for simulated river flows of different rainfall-runoff 965 models. Hydrolog Sci J, 52 (5), 896-916. https://doi.org/10.1623/hysj.52.5.896.

966 Sikka, D.R., 1999. Influence of Himalayas and snow cover on the weather and climate of India967 A review. The Himalayan Environment, 37-52.

968 Singh, O. and Kumar, M., 2013. Flood events, fatalities and damages in India from 1978 to 969 2006. Nat Haz, 69 (3), 1815-1834. https://doi.org/10.1007/s11069-013-0781-0.

970 Singh, S., Dhote, P.R., Thakur, P.K., Chouksey, A., and Aggarwal, S.P., 2020. Identification of 971 flash-floods-prone river reaches in Beas river basin using GIS-based multi-criteria 972 technique: validation using field and satellite observations. Nat Haz, 105 (3), 2431-2453. 973 https://doi.org/10.1007/s11069-020-04406-w.

974 Soulis, K.X. and Valiantzas, J.D., 2012. SCS-CN parameter determination using rainfall-runoff 975 data in heterogeneous watersheds - the two-CN system approach. Hydrol Earth Syst Sci 976 16(3), 1001-1015. https://doi.org/10.5194/hess-16-1001-2012.

977 Stefanidis, S. and Stathis, D., 2013. Assessment of flood hazard based on natural and 978 anthropogenic factors using analytic hierarchy process (AHP). Nat Haz, 68 (2), 569-585. 979 https://doi.org/10.1007/s11069-013-0639-5. 
980

981

982

983

984

985

986

987

988

989

990

991

992

993

994

995

996

997

998

999

1000

1001

1002

Stewart, D., Canfield, E., and Hawkins, R., 2012. Curve number determination methods and uncertainty in hydrologic soil groups from semiarid watershed data. J Hydrol Eng, 17 (11), 1180-1187. https://doi.org/10.1061/(ASCE)HE.1943-5584.0000452.

Subramanya, K., 2008. Engineering Hydrology. Third. New Delhi: Tata McGraw-Hill Publishing Company Limited.

Sun, J., Cao, X., Liang, H., Huang, W., Chen, Z. and Li, Z., 2020, April. New interpretations of normalization methods in deep learning. In Proceedings of the AAAI Conference on Artificial Intelligence (Vol. 34, No. 04, pp. 5875-5882). Talei, A. and Chua, L.H.C., 2012. Influence of lag time on event-based rainfall-runoff modeling using the data driven approach. J Hydrol, 438, 223-233. https://doi.org/10.1016/j.jhydrol.2012.03.027.

Tang, Q., Schilling, O.S., Kurtz, W., Brunner, P., Vereecken, H., and Hendricks Franssen, H., 2018. Simulating Flood-Induced Riverbed Transience Using Unmanned Aerial Vehicles, Physically Based Hydrological Modeling, and the Ensemble Kalman Filter. Water Resour Res, 54 (11), 9342-9363. https://doi.org/10.1029/2018WR023067.

Termeh, Seyed Vahid Razavi, Aiding Kornejady, Hamid Reza Pourghasemi, and Saskia Keesstra, 2018. Flood susceptibility mapping using novel ensembles of adaptive neuro fuzzy inference system and metaheuristic algorithms. Sci Total Environ 615, 438-451. https://doi.org/10.1016/j.scitotenv.2017.09.262.

Thakur P. K., Aggarwal, S. P., Dhote P., Nikam, B. R., Garg, V., Bhatt, C. M., Chouksey, A. and Jha, A., 2019. Hydrometeorological Hazards Mapping, Monitoring and Modelling. In: Navalgund R., Kumar A., Nandy S. (eds.) Remote Sensing of Northwest Himalayan Ecosystems, eBook ISBN:978-981-13-2128-3. Springer Singapore. https://doi.org/10.1007/978-981-13-2128-3. 
1003 Thakur, P. K., Ranjan, R., Singh, S., Dhote, P. R., Sharma, V., Srivastav, V., Dhasmana, M.,

1004 Aggarwal, S. P., Chauhan, P., Nikam, B. R., Garg, V., and Chouksey, A., 2020. Synergistic

1005 Use of Remote Sensing, Gis And Hydrological Models for Study of August 2018 Kerala

1006 Floods. Int Arch Photogramm Remote Sens Spatial Inf Sci, XLIII-B3-2020, 1263-1270,

1007 https://doi.org/10.5194/isprs-archives-XLIII-B3-2020-1263-2020.

1008 Vignesh, K.S., Anandakumar, I., Ranjan, R., and Borah, D., 2020. Flood vulnerability

1009 assessment using an integrated approach of multi-criteria decision-making model and

1010 geospatial techniques. Model Earth Syst Environ , 7(2), 767-781.

1011 https://doi.org/10.1007/s40808-020-00997-2.

1012 Watson, R.T. and Haeberli, W., 2004. Environmental threats, mitigation strategies and high-

1013 mountain areas. AMBIO: J Human Environ, 33(sp13), 2-10. https://doi.org/10.1007/0044-

1014 7447-33.sp13.2. Wu, S.-Y., Yarnal, B., and Fisher, A., 2002. Vulnerability of coastal

1015 communities to sea-level rise: a case study of Cape May County, New Jersey, USA.

1016 Climate research, 22 (3), 255-270. https://doi.org/10.3354/cr022255.

1017 Xiao, Y., Yi, S., and Tang, Z., 2017. Integrated flood hazard assessment based on spatial

1018 ordered weighted averaging method considering spatial heterogeneity of risk preference.

1019 Sci Total Environ, 599, 1034-1046. https://doi.org/10.1016/j.scitotenv.2017.04.218.

1020 Xs, H.R., Ross-larson, B., De Coquereaumont, M., Trott, C., Watkins, K., Carvajal, L., Ghosh,

1021 A., and Johansson, C., 2006. Human development report 2006.

1022 Yalcin, E., 2020. Assessing the impact of topography and land cover data resolutions on two-

1023 dimensional HEC-RAS hydrodynamic model simulations for urban flood hazard analysis.

1024 Nat Haz, 101 (3), 995-1017. https://doi.org/10.1007/s11069-020-03906-z.

1025 Yan, K., Di Baldassarre, G., Solomatine, D.P., and Schumann, G.J., 2015. A review of low-cost 
1026 space-borne data for flood modelling: topography, flood extent and water level. Hydrol 1027 Process, 29 (15), 3368-3387. https://doi.org/10.1002/hyp.10449.

1028 Yoon, D.K., 2012. Assessment of social vulnerability to natural disasters: A comparative study.

1029 Nat Haz, 63 (2), 823-843. https://doi.org/10.1007/s11069-012-0189-2.

1030 Young, C.C. and Liu, W.C., 2015. Prediction and modelling of rainfall-runoff during typhoon 1031 events using a physically-based and artificial neural network hybrid model. Hydrological 1032 Sciences Journal, 60 (12), 2102-2116. https://doi.org/10.1080/02626667.2014.959446.

1033 Žurovec, O., Čadro, S., and Sitaula, B.K., 2017. Quantitative assessment of vulnerability to 1034 climate change in rural municipalities of Bosnia and Herzegovina. Sustainability), 9 (7), 1035 1208. https://doi.org/10.3390/su9071208.

1036 


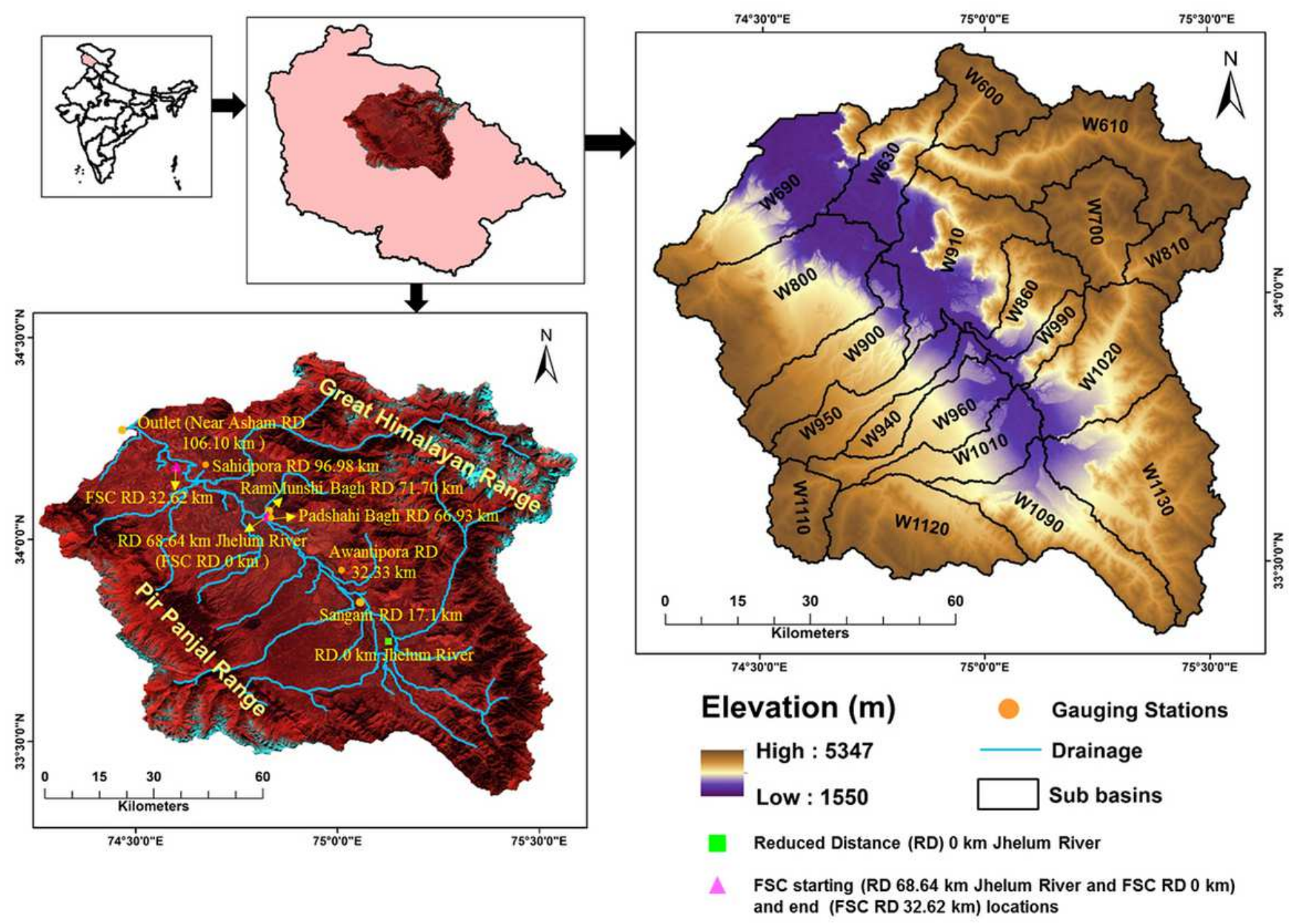

Figure 1

Jhelum River basin with outlet, drainages, sub-basins \& gauging sites 


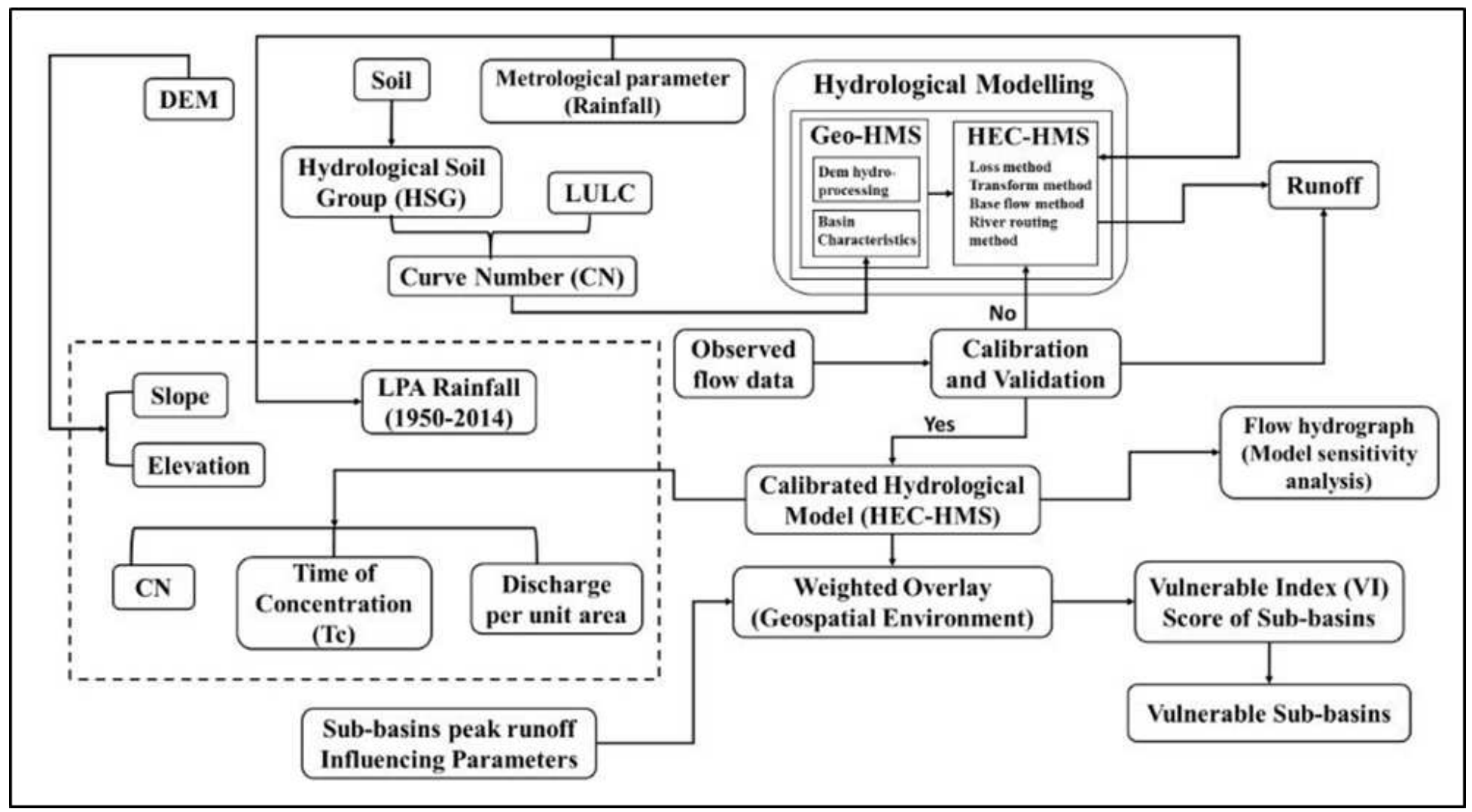

Figure 2

Methodology flowchart

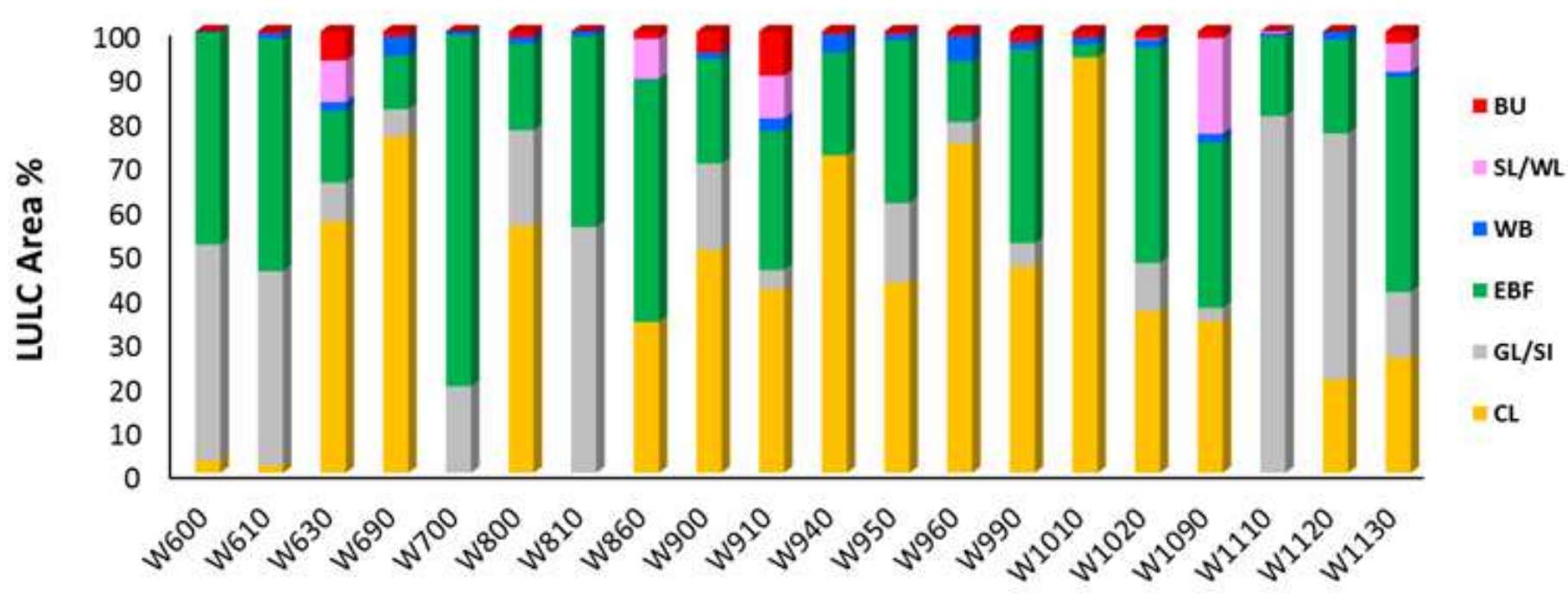

Sub-basins

Figure 3

LULC percent of each sub-basin 


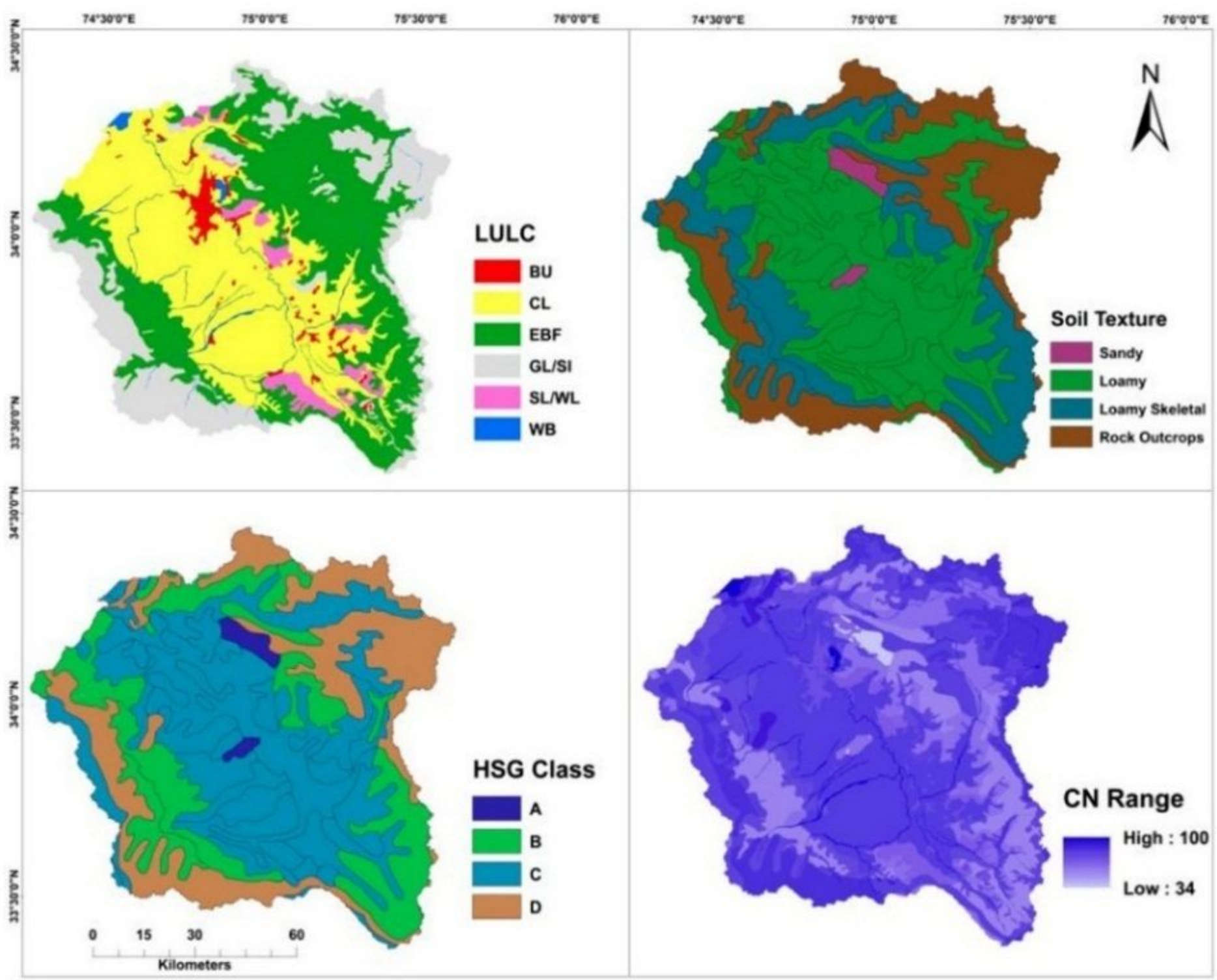

Figure 4

LULC, Soil, HSG and CN Map of Jhelum basin 


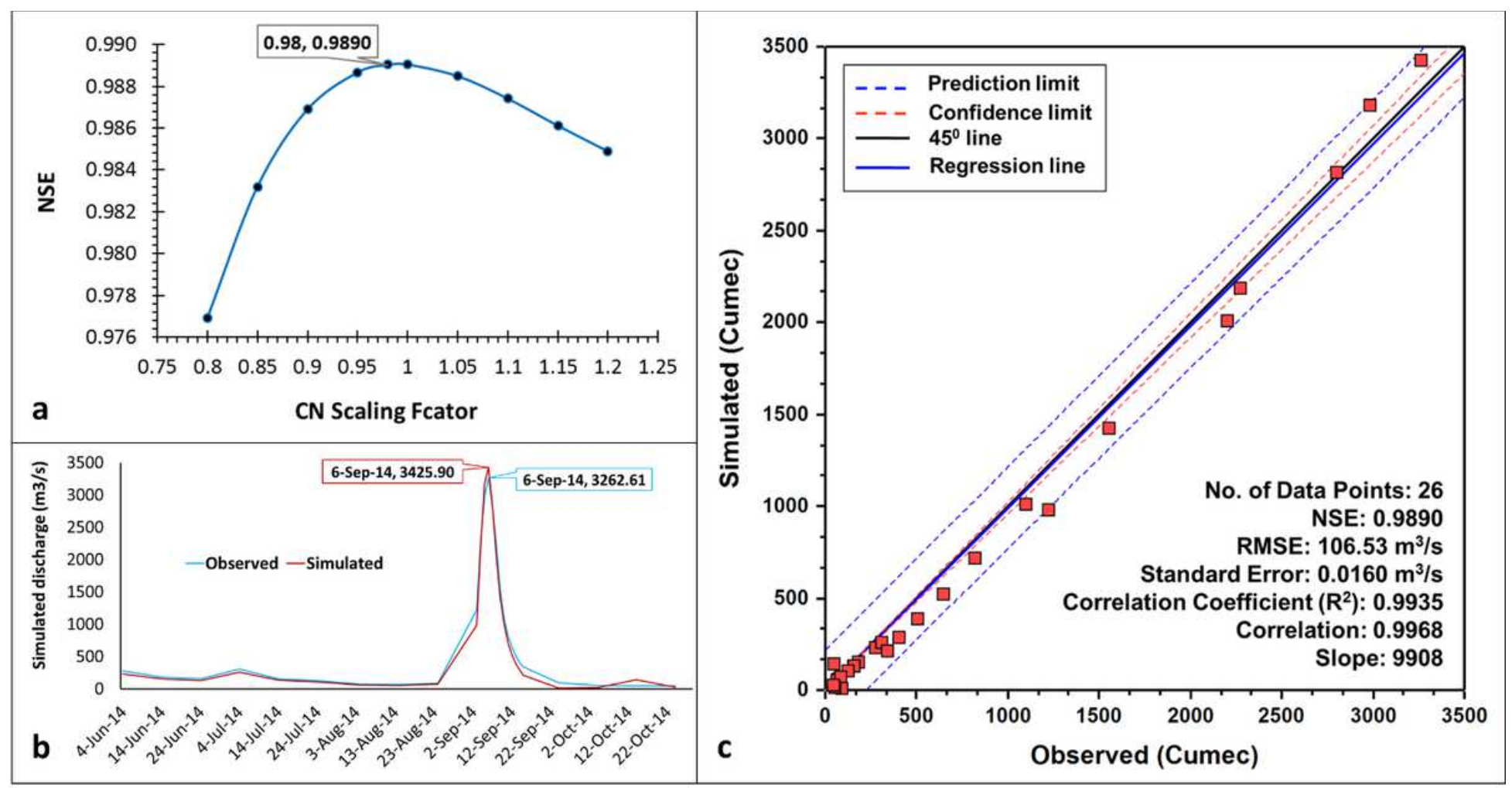

Figure 5

Calibration (2014) at Sangam: a) Model Sensitivity, b) Time Series, and c) Scattered plot

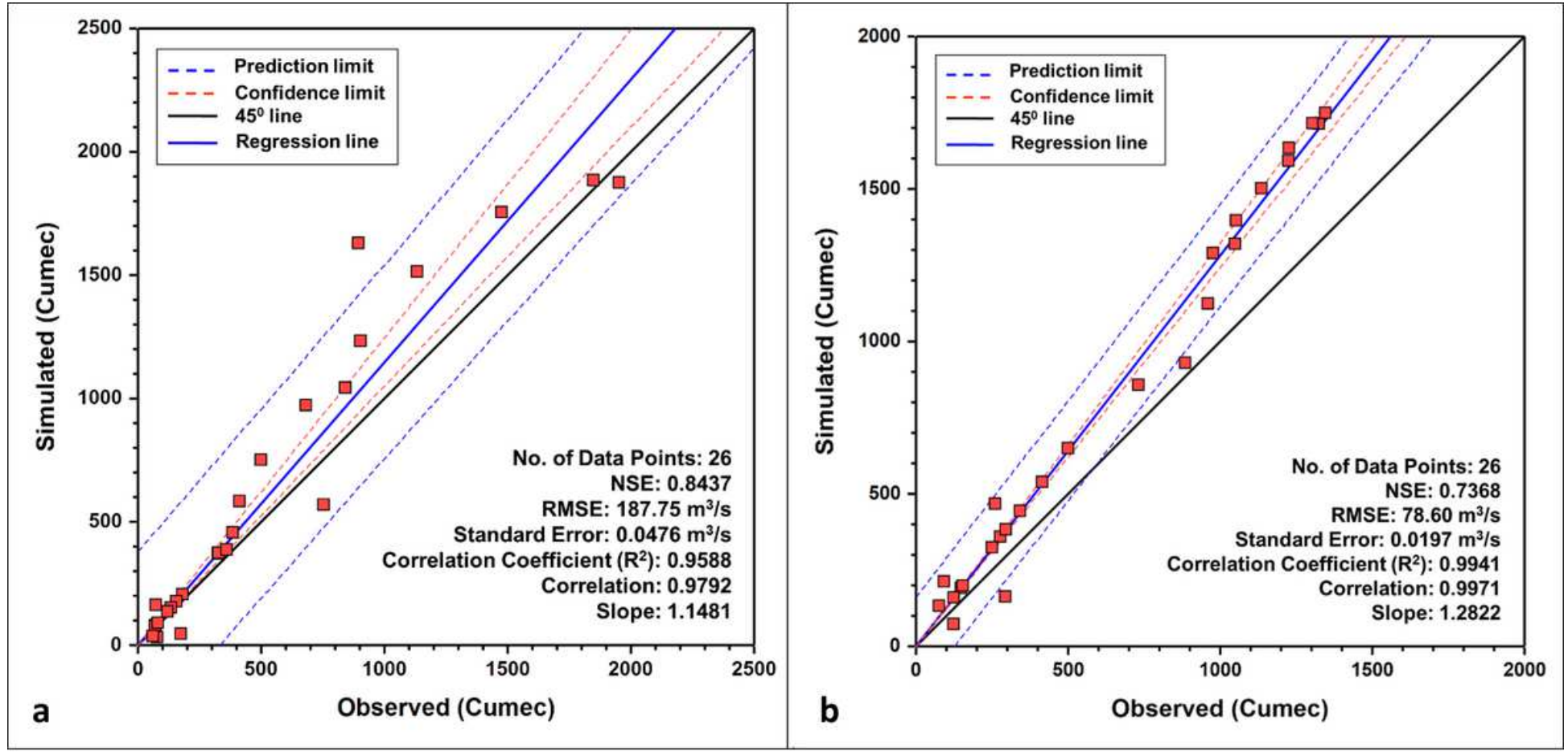

Figure 6

Scattered plots (2014) at other stations: a) RamMunshi Bagh and b) Asham 


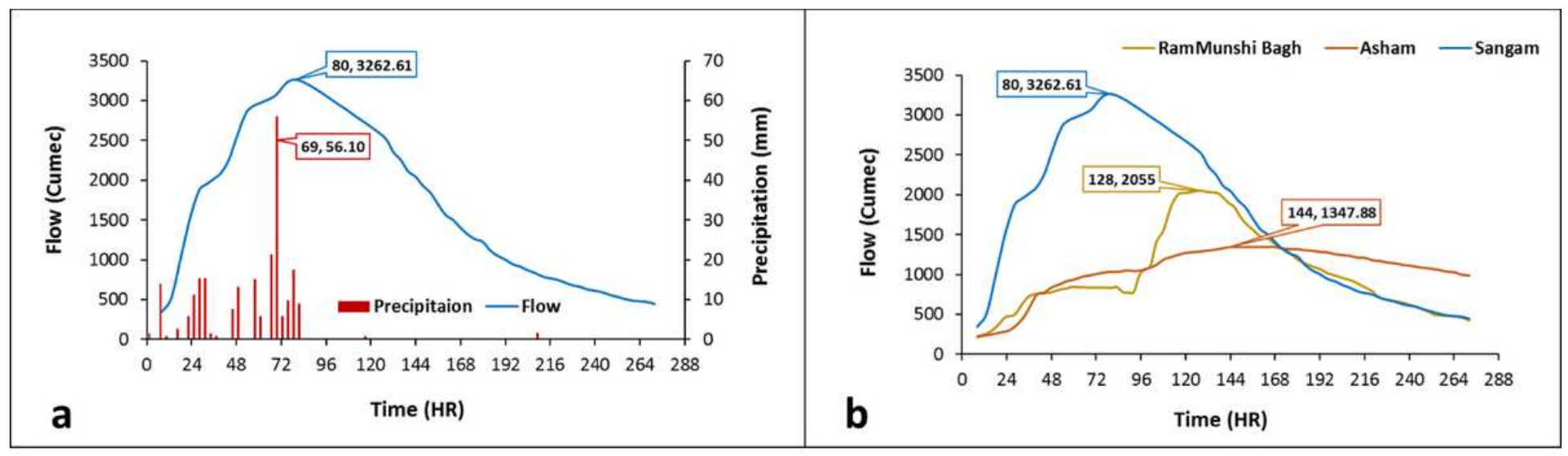

Figure 7

a) Time lag (2014) at Sangam; b) flow (2014) at Sangam, RamMunshi Bagh \& Asham

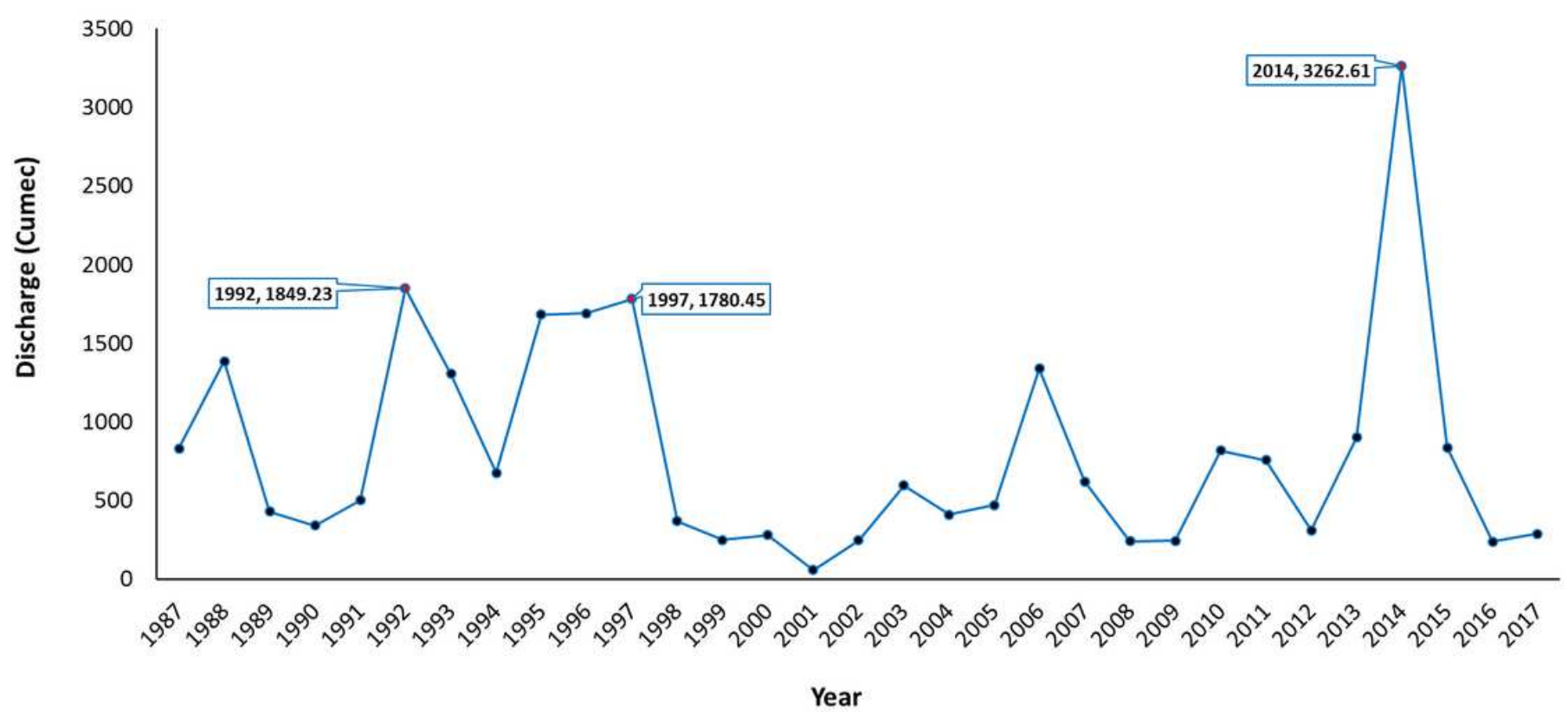

Figure 8

Year wise maximum flow at Sangam 


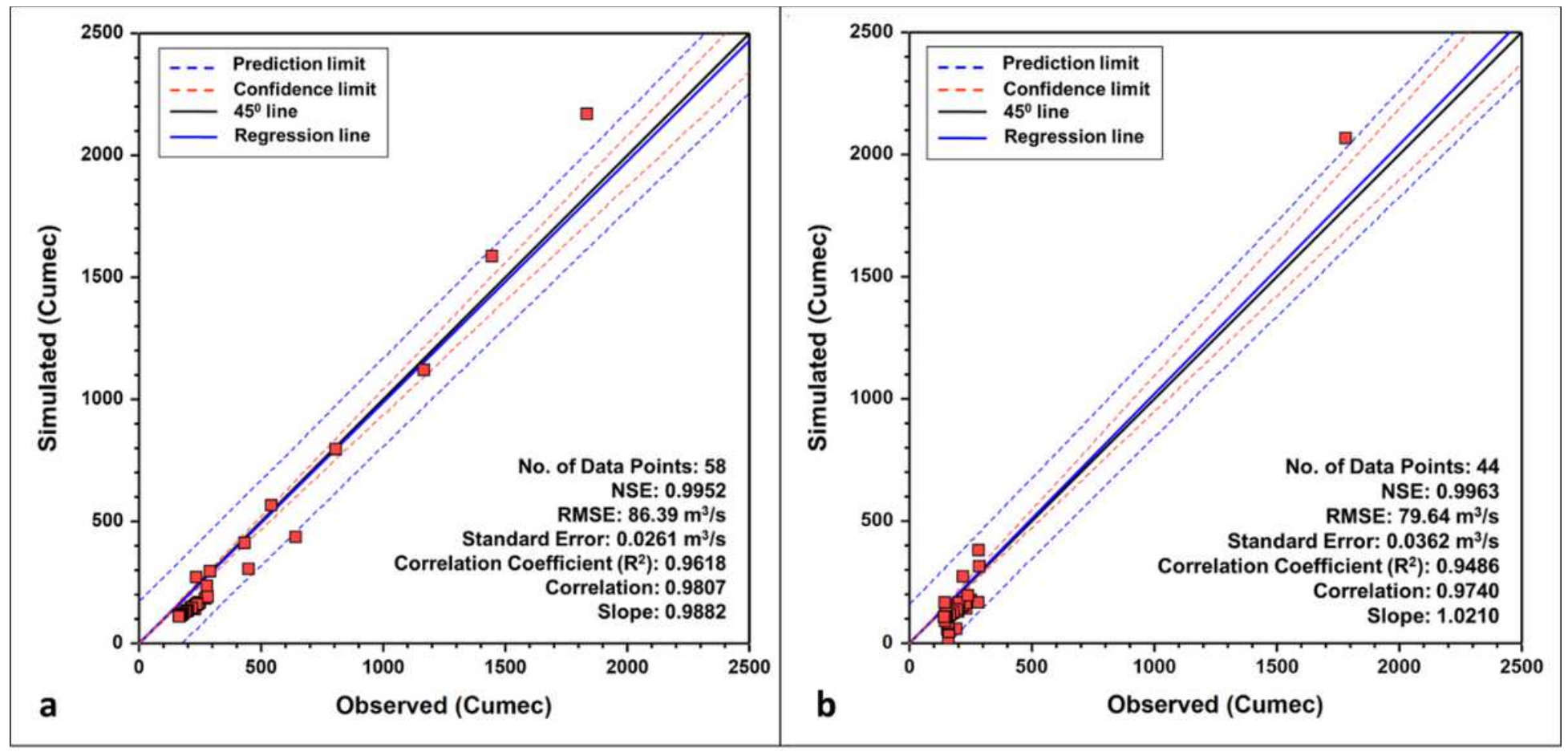

Figure 9

Validation scattered plots at Sangam: a) year 1992 and b) year 1997

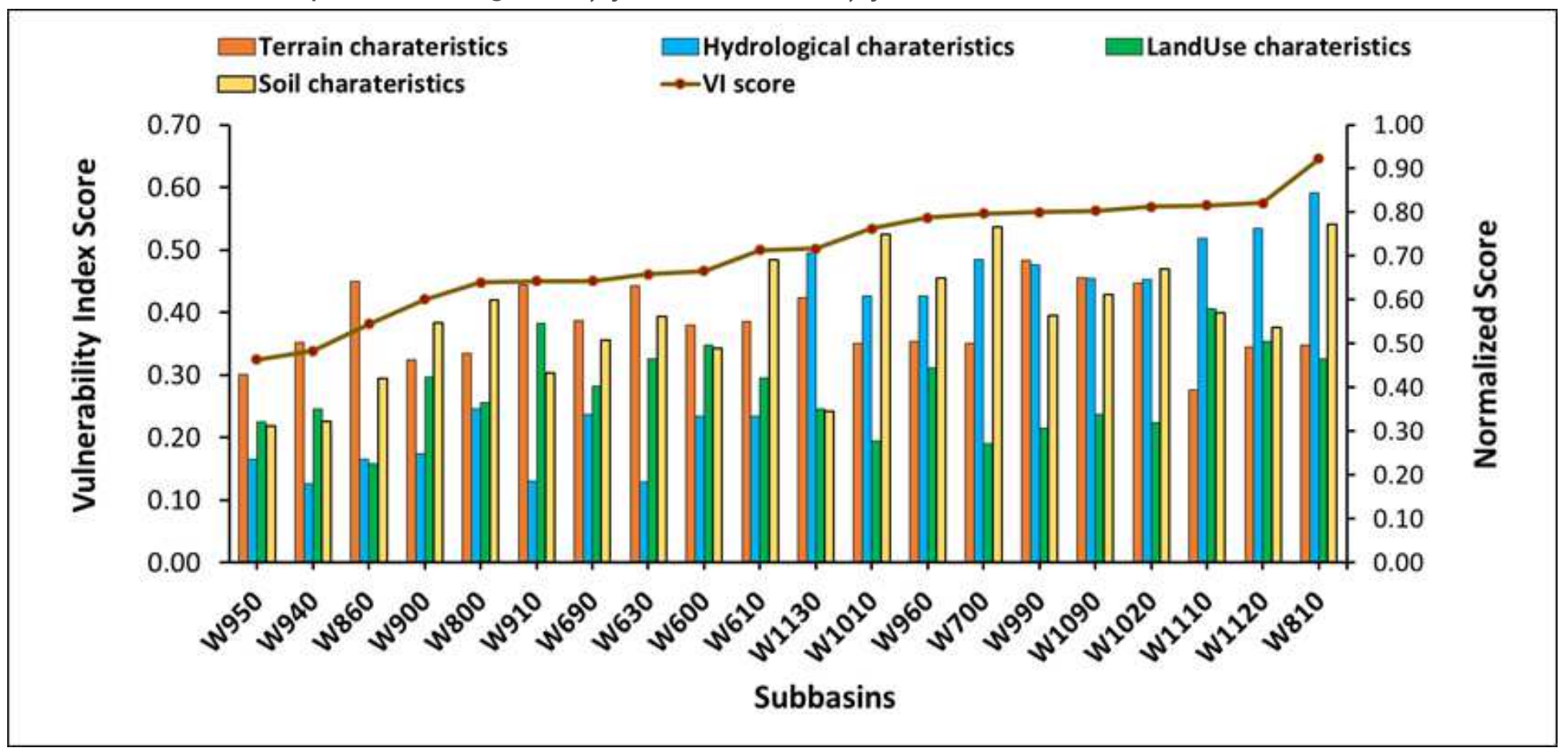

Figure 10

Sub-basins wise Vulnerability Index score plot with their classification using the color ramp representation and the normalized score plot of their characteristics 


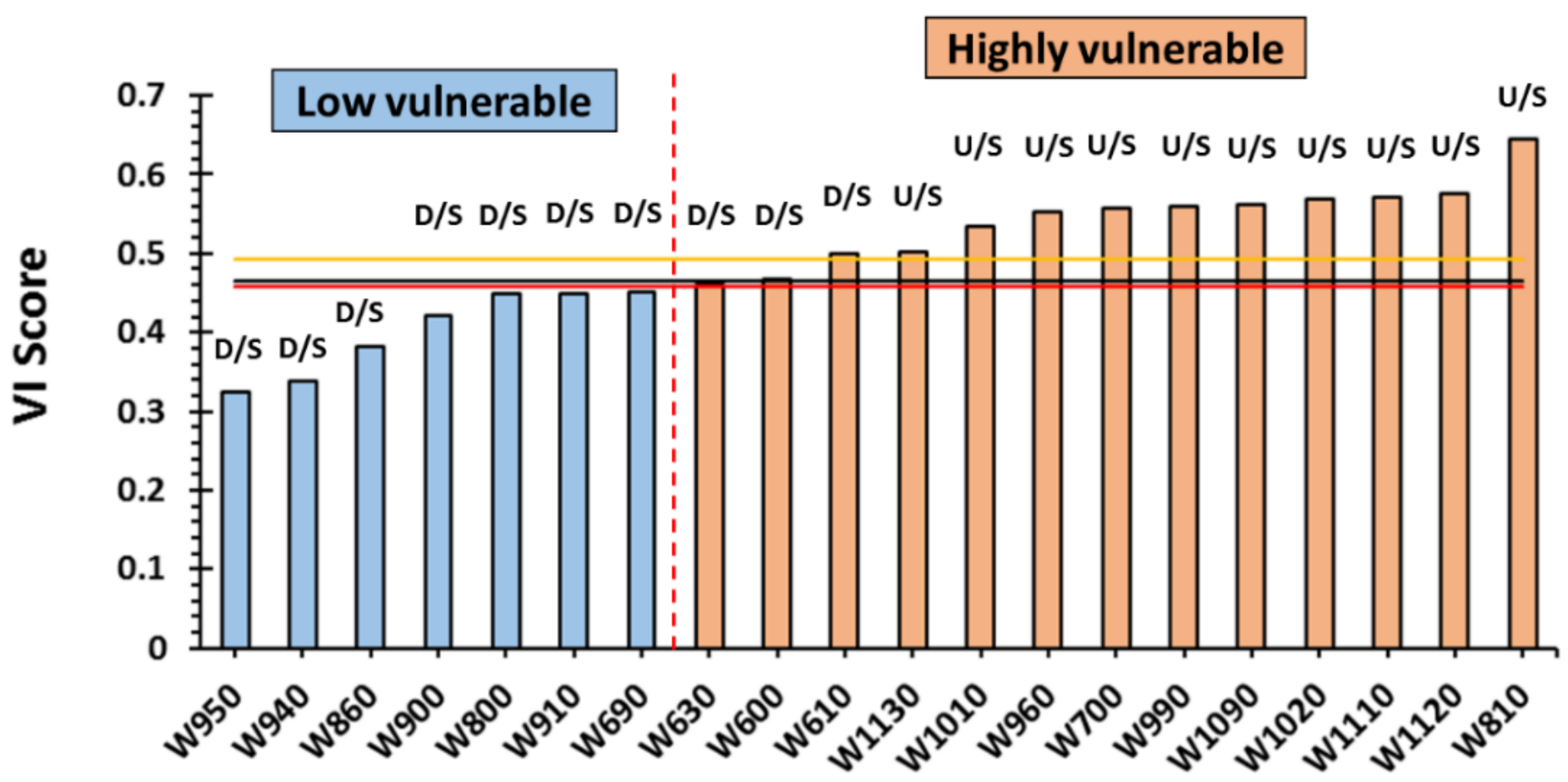

Figure 11

$\mathrm{D} / \mathrm{S}=$ Downstream (contributing to RamMunshi Bagh and Asham) and U/S = Upstream (contributing to Sangam)
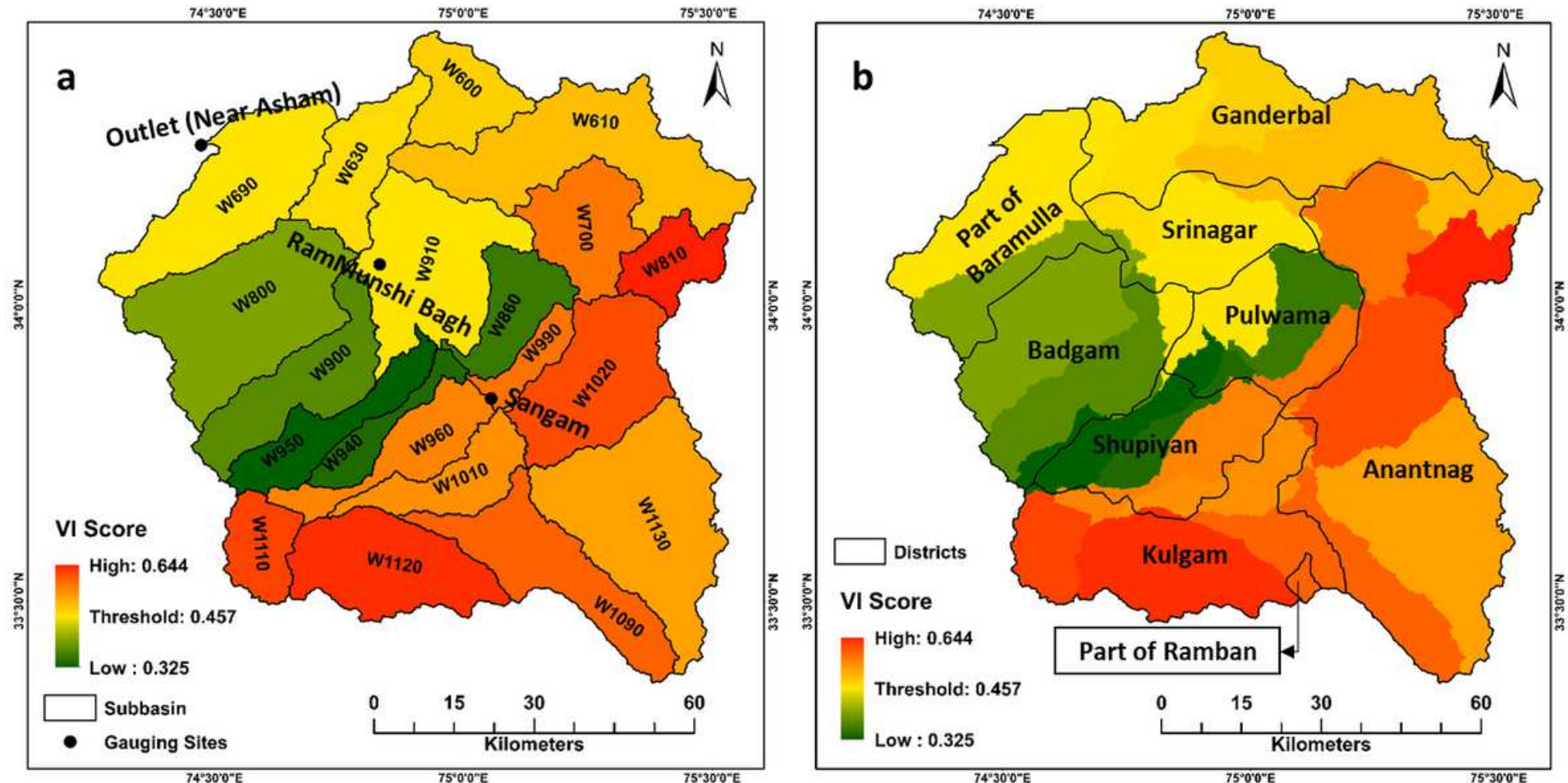
Figure 12

Vulnerability Index score map: a) sub-basins wise, and b) district wise

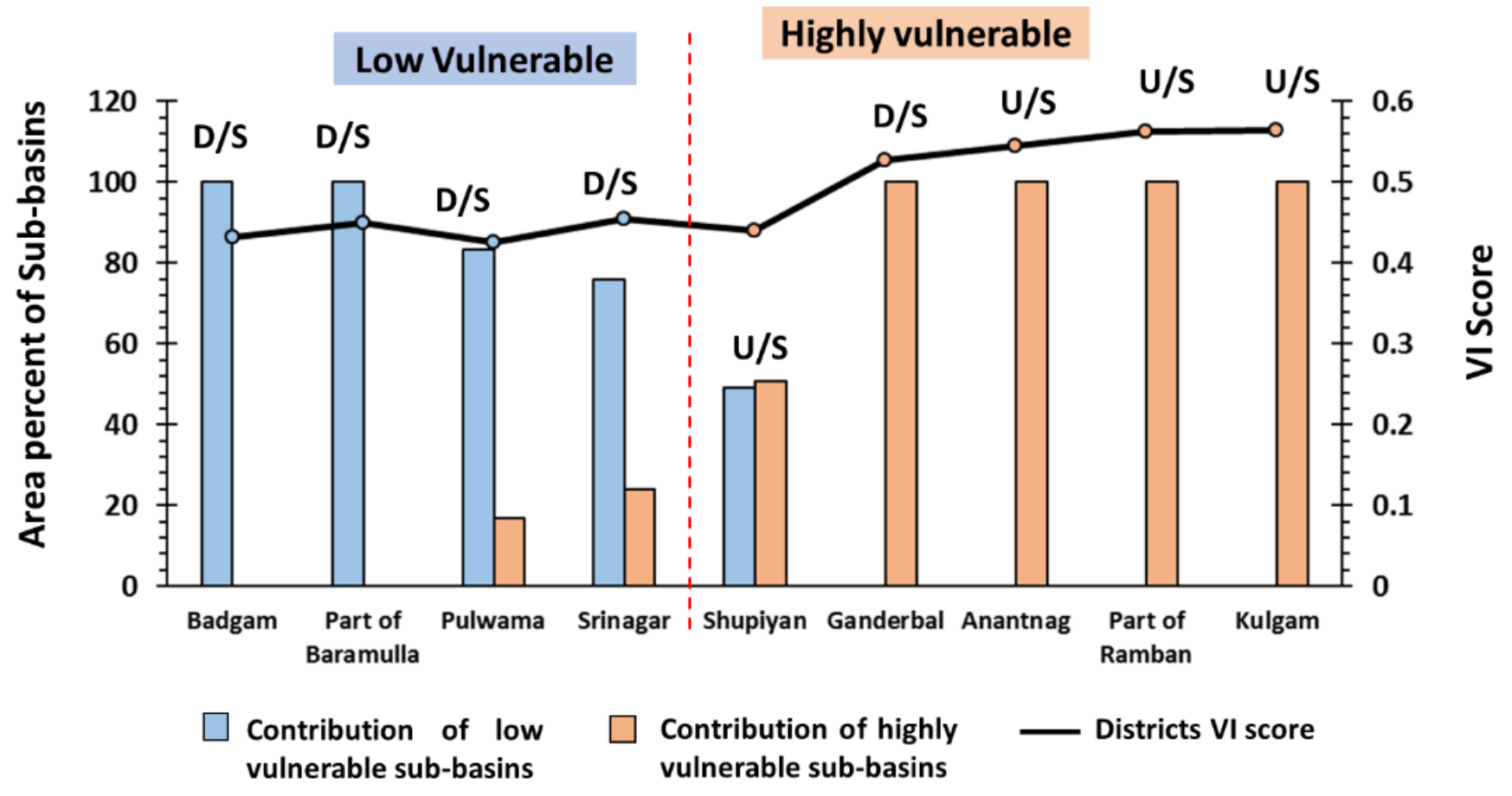

Figure 13

Area contribution of sub-basins in the respective districts and district wise VI score 